\title{
Patterns, processes and regulatory mechanisms in sandy beach macrofauna: a multi-scale analysis
}

\author{
Omar Defeo $^{1, *}$, Anton McLachlan ${ }^{2}$ \\ ${ }^{1}$ Centro de Investigación y de Estudios Avanzados del IPN, AP 73 Cordemex, 97310 Mérida, Yucatán, México \\ ${ }^{2}$ College of Agricultural and Marine Sciences, Sultan Qaboos University, Oman
}

\begin{abstract}
Physical and biological factors govern community and population features of sandy beach macrofauna. At the macroscale, species richness decreases from tropical to temperate beaches, and from macrotidal dissipative to microtidal reflective beaches. At the species level, life history traits are highly plastic over latitudinal gradients; large-scale variations in environmental variables modulate intraspecific phenotypic differentiation. At the mesoscale, alongshore and across-shore distributions tend to be unimodal, bell-shaped within a beach, with abundance varying from the central region to the boundaries, even though environmental gradients (wave exposure, salinity) can cause asymmetries. Zonation is highly dynamic and not sharply defined. This is attributed to short- (hourly, daily) or medium- (seasonal) term reactions to environmental conditions, passive transport and sorting by the swash (e.g. recruits), active micro-habitat selection (e.g. adults), and intra- and interspecific interactions. Across-shore distribution may become multimodal due to intraspecific segregation by sizes during recruitment. At the microscale (individual neighbourhood or quadrat scale), behavioural factors and intra-/interspecific interactions become more important as density increases. Human induced impacts also generate variability in population demography, structure and dynamics. We identify physical-biological coupling at different temporal and spatial scales, emphasizing the role of life history traits in order to assess alternative regulatory mechanisms and processes. Our synthesis suggests that: (1) biological interactions are more important regulatory agents than previously thought: in benign dissipative beaches or undisturbed sites, intra- and interspecific competition can be more intense than in reflective beaches or disturbed sites, where the populations are physically controlled; (2) supralittoral forms are relatively independent of the swash regime and show no clear response to beach type; (3) marked long-term fluctuations are noticeable in species with planktonic larvae structured as metapopulations, due to environmental disturbances and stochasticity in reproduction and recruitment.
\end{abstract}

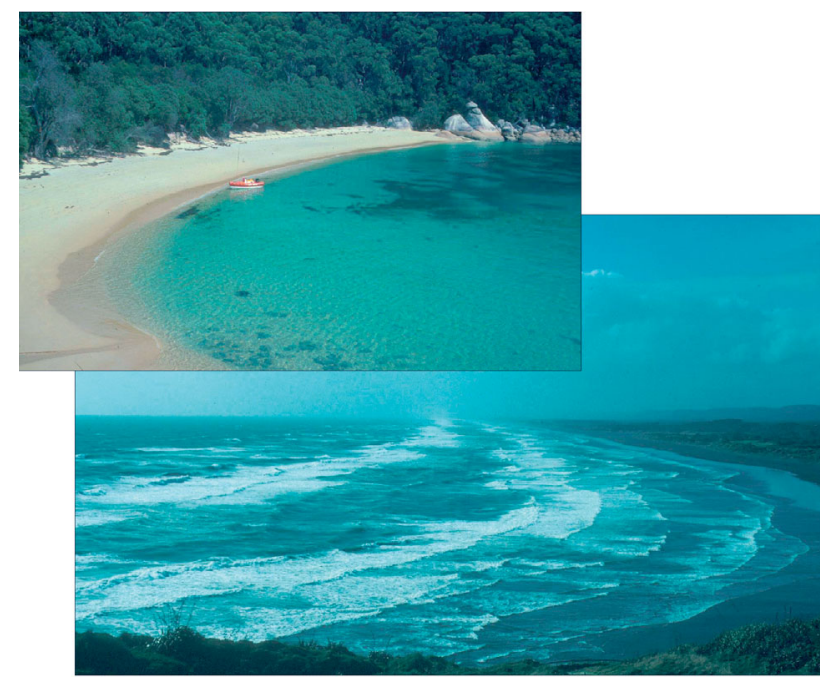

Sandy beaches are defined by just 3 factors — tide regime, sand particle size and wave energy - and occur as a range from reflective (upper) to dissipative (lower) types. Since macrofauna show clear patterns of response to beach type, these simple environments provide a unique opportunity to explore processes controlling community and population ecology. Photos by Dr. Andrew Short (University of Sydney, Australia)

KEY WORDS: Sandy beaches $\cdot$ Macrofauna $\cdot$ Communities $\cdot$ Populations $\cdot$ Patterns $\cdot$ Regulation $\cdot$ Processes

$$
\text { Resale or republication not permitted without }
$$
written consent of the publisher

\section{INTRODUCTION}

At the time of the first international sandy beach symposium in 1983, sandy beach research was in a transition from early, mainly qualitative studies of macrofauna ecology and ecophysiology, to quantitative work (McLachlan \& Erasmus 1983). Studies on energy flow and nutrient cycling in beach ecosystems 


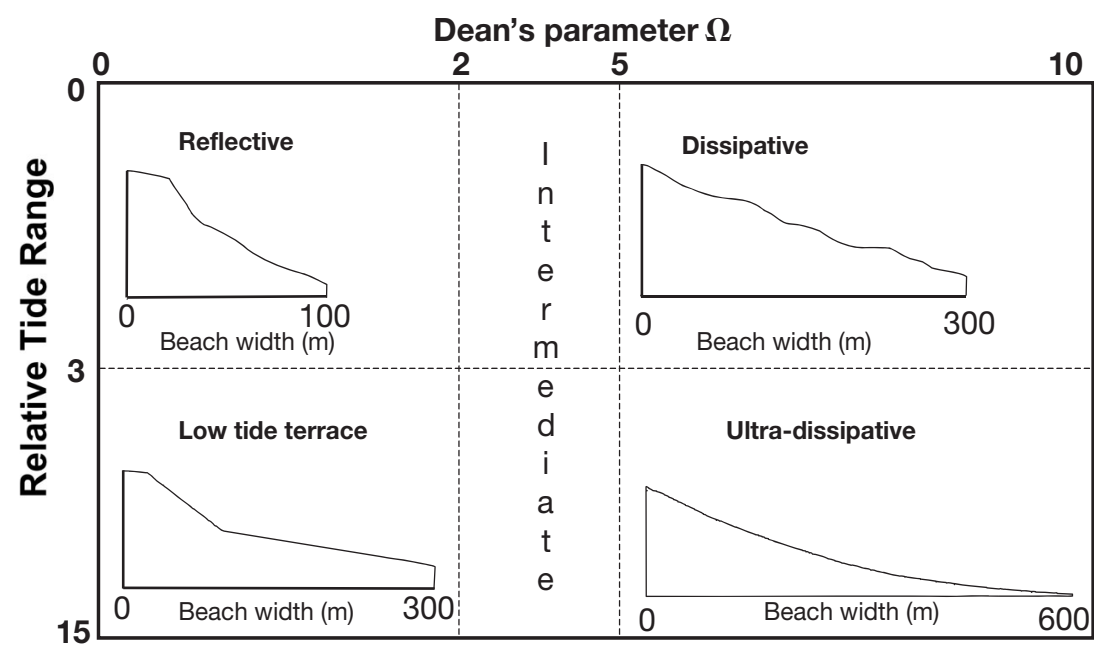

Fig. 1. Beach classification based on 2 composite indices developed for sandy shores: Dean's parameter $(\Omega)$ and the Relative Tide Range. Dissipative, intermediate and reflective domains are defined for microtidal open beaches where tide range $<2 \mathrm{~m}$ (after Short 1996) produce a range of beach morphodynamic types which span a continuum from microtidal reflective beaches, narrow and steep, to macrotidal dissipative systems, which are wide and flat, and under conditions of large tides, grade into tidal flats (for review see Short 1996). The most accretional state is the reflective beach, formed under condition of small tides and waves and coarse sand; here there is no surf zone and wave energy is reflected back to sea from waves breaking directly on the steep beach face. In erosional or dissipative states the beach is flat and fronted by a wide surf zone, in which waves dissipate much of their energy. The dissipative state forms under conditions of large tide range, high wave energy, fine sand, and tends to be more prevalent at higher latitudes. A

remained a dominant theme through the 1980s. In the 1990s most sandy beach research focused on community and population ecology. Beach research lagged far behind studies of other coastal environments, and before 1980 it lacked a body of theory to drive it, but this has steadily changed. Although they are still less studied than most other coastal systems, beaches are much better characterized in the new millennium. A significant body of knowledge has accumulated and a variety of hypotheses concerning sandy beach ecosystems and communities have been developed, so that beach studies have become increasingly theory driven. In this review we summarize the current status of community and population ecology for sandy beach macrofauna (hyperbenthos not included), focusing on key processes operating at different scales, and on how they interact to yield the patterns observed. We also refine the theory, identifying the physicalbiological coupling at different temporal and spatial scales and emphasising the role of life history traits in order to assess the magnitude of alternative regulatory mechanisms.

\section{THE BEACH ENVIRONMENT}

The benthic macrofauna of sandy beaches includes representatives of many phyla, but crustaceans, molluscs and polychaetes are usually dominant and can be divided into intertidal and supralittoral forms (Brown \& McLachlan 1990). Their habitat is dynamic and defined by 3 factors: tides, waves and sand. The interactions between tidal regime, wave climate and sediment type series of intermediate states are recognized between the above extremes (Fig. 1).

Various indices of beach type have been used by ecologists. Dean's dimensionless fall velocity $(\Omega)$, a measure of how reflective or dissipative a microtidal beach is (Short 1996), is defined as:

$$
\Omega=\frac{H b}{W s \cdot T}
$$

where $H b$ is breaker height $(\mathrm{m})$, Ws is sand fall velocity $\left(\mathrm{m} \mathrm{s}^{-1}\right.$ ) and $T$ is wave period ( $\left.\mathrm{s}\right) . \Omega<2$ characterizes reflective beaches, whereas $\Omega>5$ defines dissipative ones and $2<\Omega<5$ characterizes intermediate beach states (Fig. 1). Essentially, $\Omega$ is a measure of the ability of the prevalent wave energy to erode sand. Another measure of beach type is relative tide range $\mathrm{RTR}=$ $T R / H b$, where $T R$ is spring tide range $(\mathrm{m})$. RTR indicates the relative importance of tides versus waves in controlling beach morphodynamics (Fig. 1). As $\Omega$ does not take tides into account, the Beach State Index (BSI) has been used to compare beaches subject to differing tide ranges; BSI is $\Omega$ multiplied by tide range and indicates the ability of waves and tides to move sand (McLachlan et al. 1993). Soares (2003) developed the Beach Deposit Index (BDI), a composite index of beach slope and grain size. Recently, McLachlan \& Dorvlo (2005) developed the beach index (BI):

$$
B I=\log _{10}\left(\frac{M z \cdot T R}{S}\right)
$$

where $M z$ is the mean grain size (in phi units +1 , to avoid negative values), $T R$ is the maximum spring tide range $(\mathrm{m})$ and $S$ is beach face slope (dimensionless). 
Water movement over the beach face, after a broken wave (bore) collapses on the sand, is termed swash (McArdle \& McLachlan 1991, 1992). In reflective beaches, waves break directly on the beach face generating harsh swash climates, i.e. dynamic, turbulent swashes with short periods, with many swashes running above the sand water saturation level, and water draining rapidly into the coarse sand. Conversely, dissipative systems have benign swashes, where much of the wave energy is consumed in the surf zone so that swashes reaching the beach face tend to be less turbulent and have longer periods; swashes seldom go above the saturated beach face so there is little drainage into the sand (McLachlan \& Turner 1994). Sandy beach macrofauna experience this environment through 3 suites of physical factors:

the sediment texture and movement, the swash climate, and the exposure/moisture gradient on the beach face (Brown \& McLachlan 1990). Sediment texture and movement includes particle size, sorting, fluidity and accretion/erosion dynamics. Swash climate includes the swash period, speed, turbulence and water movement over and into the beach face. The intertidal gradient is the degree of aerial exposure of the sediment surface and the changing moisture content of the sand over the tidal cycle.

\section{LARGE-SCALE VARIATIONS}

The large scale, or macroscale, concerns biogeographic patterns in community and population features, including variations over beaches with different morphodynamics.

\section{Communities}

Latitudinal patterns

Matching the pattern recorded for other environments (Willig et al. 2003), species richness increases from temperate to tropical sandy beaches (Fig. 2) (Hacking 1997, McLachlan et al. 1998, Soares 2003, McLachlan \& Dorvlo 2005). This contradicts the earlier pattern found by Dexter (1992), who did not take into account beach type; the above studies allowed for beach type by comparing species richness against physical variables or compound indices of beach state (e.g. BSI, $\Omega$ ). Latitudinal variation in beach type is crit- ical to elucidate these large patterns; tropical regions had a greater proportion of reflective beaches than subtropical or temperate regions, the latter being dominated by dissipative beaches because of higher wave energy and fine sand (Soares 2003, McLachlan \& Dorvlo 2005).

Following the opposite trend, abundance and biomass increase from tropical to temperate beaches (Fig. 2), although these trends are less clear for polychaetes and molluscs than for crustaceans (Soares 2003, McLachlan \& Dorvlo 2005). Greater abundance and biomass on temperate dissipative beaches could be attributed to greater food availability, due to greater productivity mainly provided by abundant benthic fauna and surf zone phytoplankton (McLachlan 1990). The presence of surf diatom accumulations has led to the definition of dissipative beaches as semi-closed ecosystems (sensu McLachlan 1980), in contrast to reflective beaches, defined as interfaces with low productivity, subsidized by organic inputs from the sea (Brown \& McLachlan 1990). Whereas increased wave energy in temperate areas seems to cause increased productivity and biomass, stranded seagrass or algae (Colombini \& Chelazzi 2003), or the presence of upwelling (Jaramillo et al. 2001) can also add to sand beach energetics and biomass.

\section{Relationships with physical parameters}

McLachlan (2001) identified 3 paradigms which define large scale community patterns on exposed sandy beaches: (1) the concept of overriding physical control in harsh environments, (2) the beach morphodynamic models (Fig. 1), and (3) the increase of species 

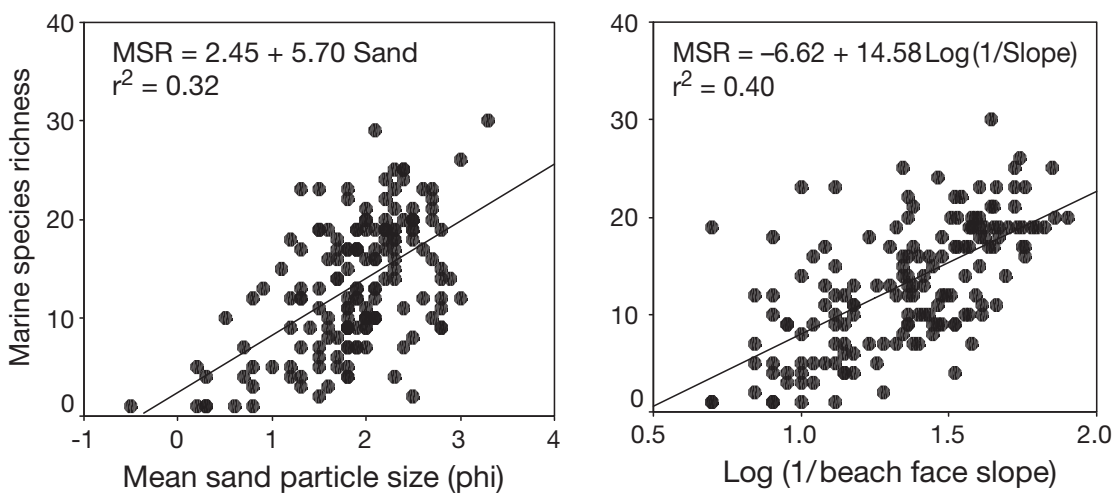

tides may be due to the fact that most workers compared regions subject to a fairly uniform tide range.

The response of abundance to changes in individual physical factors and to composite indices of beach state is exponential, being more variable than the response of species richness. Biomass, which also responds exponentially, is the most variable of the 3 community measures and seems to be related to the amount of wave energy, which may indicate productivity (McLachlan 1990, McLachlan et al. 1993, Nel 2001, Soares 2003). McLachlan \& Dorvlo (2005) showed that abundance and biomass exponentially decrease with intertidal beach face slope (see also Defeo et al. 1992a, Nel 2001, Brazeiro 2001, G. Stephenson \& A. McLachlan unpubl.). Slope is closely related to swash climate, which becomes less harsh as beach face slope flattens, indicated by longer swash periods, less swash activity above the effluent line, and less turbulence (McArdle \& McLachlan 1991, 1992). Beach face slope is thus both a

richness, abundance and biomass from microtidal reflective to macrotidal dissipative beaches.

Beach environments largely lack biogenic structure and are extremely dynamic in space and time. Thus, their intertidal macrofauna is considered to be physically controlled in the sense of the Autecological Hypothesis (Noy-Meir 1979). This hypothesis, as adapted by McLachlan (1990), states that sandy beaches are physically controlled environments where communities are structured by the independent responses of individual species to the physical environment, biological interactions being minimal. A main prediction of this hypothesis is the increase in community descriptors from harsh reflective to benign dissipative beaches. In agreement with this prediction, sandy beach communities increase in richness, density, total abundance and biomass from microtidal reflective beaches to macrotidal dissipative beaches (McLachlan et al. 1981, 1993, 1996a, McLachlan 1990, Jaramillo et al. 1995). McLachlan \& Dorvlo's (2005) analysis of worldwide data also showed that species richness decreases with coarser sand, steeper beach face slope, and smaller tide range (Fig. 3). Increasing tide range makes beaches more dissipative (McLachlan \& Dorvlo 2005), creating a vertical exposure gradient along which intertidal species establish themselves, with wave effects being secondary. Neglect of the role of measure of the dimensions of the intertidal zone and an index of swash climate and beach type.

In the context of the Autecological Hypothesis, the pattern of species richness was explained as exclusion of species from the reflective end of the gradient of beach types by a harsh swash climate. This idea was refined as the Swash Exclusion Hypothesis (SEH: McLachlan et al. 1993), based on the finding that the swash climate which the macrofauna experience on the beach face is closely coupled to beach type (McArdle \& McLachlan 1991, 1992). Exclusion of species towards the reflective end of the beach morphodynamic spectrum may be due to both harsh swash climate and coarse sands, as reflected by strong relationships between community attributes and compound indices of beach state (e.g. BI, BSI, Dean's parameter) or individual physical factors (McLachlan, 1990, Defeo et al. 1992a, Hacking 1997, Brazeiro 1999, Ricciardi \& Bourget 1999, Jaramillo et al. 2000a, Nel 2001, Soares 2003, Rodil \& Lastra 2004, McLachlan \& Dorvlo 2005, G. Stephenson \& A. McLachlan unpubl.).

The mechanisms which explain the presence or absence of species across the continuum of beach types have not been fully elucidated (McLachlan 2001). Ignoring the effects of latitude and exposure, swash climate and sand particle size define the immediate environment experienced by macrofauna, so that 
increasing harshness in these factors (coarse sediment, short and turbulent swashes and accretion-erosion dynamics: the expanded SEH or Multicausal Environmental Severity Hypothesis) may exclude species from reflective systems (Alexander et al. 1993, McLachlan et al. 1995, Nel 1995, 2001, Dugan et al. 2000, Brazeiro 2001, Defeo et al. 2001, Veloso \& Cardoso 2001, G. Stephenson \& A. McLachlan unpubl.). Soares (2003) questioned whether the exclusion of species towards the reflective extreme was due to pre- or post-settlement processes. Defeo et al. $(2001,2003)$ formulated the Habitat Harshness Hypothesis (HHH), postulating that in reflective beaches the harsh environment forces organisms to divert more energy towards maintenance, resulting in lower fecundity and higher mortality. Thus, post-settlement processes may prevent some species from establishing populations on reflective beaches. We postulate that species richness is therefore mainly controlled by the physical environment on the large scale (Fig. 4). At a finer scale and under more dissipative conditions, biological factors may become more important (Defeo et al. 2003, McLachlan \& Dorvlo 2005).

\section{Populations}

\section{Latitudinal patterns}

Identification of large scale patterns underpinning species' distributions in sandy beaches is often limited by the short time series of population variables, the restricted spatial coverage of most studies, and the use of different methodologies. Many studies have been based on snapshot sampling of a large number of beaches, but this does not elucidate variations in population features (Defeo 1996a).

Early studies of latitudinal patterns in sandy beach populations found large scale variations in life history traits of cirolanid isopods, notably in reproduction (Fish 1970, Jones 1970), distribution (Klapow 1970, Glynn et al. 1975, Dexter 1977), morphological and genetic variations (Weinberg \& Starczak 1988, 1989, Lessios et al. 1994, Lessios \& Weinberg 1994) and sediment preferences (Defeo et al. 1997). Marked variations in reproductive traits were also detected in Emerita species (Wenner et al. 1987, Dugan et al. 1991, 1994, Defeo \& Cardoso, 2002, 2004), which were inversely related to surf zone water temperatures and positively related to food availability in dissipative systems. A review of 15 clam species from ocean beaches around the world showed that bivalves with larger individual sizes and biomass dominate dissipative beaches of temperate zones, whereas smaller species are found on subtropical reflective beaches (McLachlan et al. 1996b).

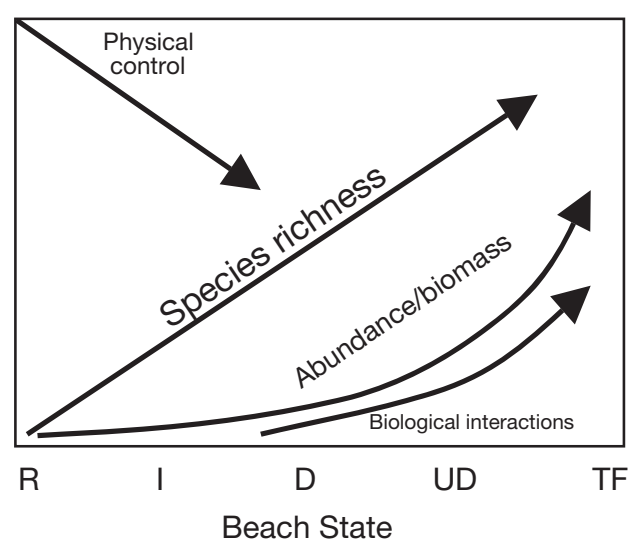

Fig. 4. General conceptual model relating biological descriptors and beach state. Species richness and abundance increase from reflective beaches to tidal flats. Towards the reflective domain, species richness is mainly controlled by the interaction of physical factors such as sand, tides, waves, and beach face slope. At a finer scale and under more dissipative conditions, biological factors become more important. $(\mathrm{R}=$ reflective, $\mathrm{I}=$ intermediate, $\mathrm{D}=$ dissipative, $\mathrm{UD}=$ ultradissipative, $\mathrm{TF}=$ tidal flat)

Large-scale studies, recently conducted on the mole crab Emerita brasiliensis (planktonic larvae) and the cirolanid isopod Excirolana braziliensis (ovoviviparous) in South America, showed systematic and recurrent patterns in population features within their range (Defeo \& Cardoso 2002, 2004, Cardoso \& Defeo 2003, 2004). The main findings were changes from temperate to tropical beaches (Fig. 5), namely increases in abundance, growth and mortality rates, reduced predominance of females, a shift from seasonal to continuous reproduction, and decreases in individual size of ovigerous females, fecundity, length at maturity, mass and longevity. Scaling of population density to body size was observed for Emerita, with densities and body mass ranging over more than 2 orders of magnitude. These patterns did not hold for male mole crabs, which showed increasing occurrence, individual sizes and growth intensity towards subtropical beaches, where the predominance of females was significantly lower. Moreover, the greater total densities in subtropical reflective beaches (Defeo \& Cardoso 2004) contradict worldwide trends that show greater macrofauna abundance (community level) occurring in dissipative beaches (McLachlan 2001). Thus, large-scale variations in abundance were ascribed to other factors operating at larger spatial scales (e.g. temperature), whereas departures from the patterns were attributed to the response to local variations in physical (e.g. beach morphodynamics and exposure) and biological (e.g. competition) characteristics rather than to biogeographic effects (Defeo \& Cardoso 2004). Asymmetries and converse latitudinal trends between sexes, cou- 
pled with studies conducted from local to large spatial scales (Defeo et al. 1997, Fiori \& Defeo 2005), suggest that sandy beach populations are regulated by densitydependent processes operating at the mesoscale (see below) and environmental factors acting together.

Phenotypic plasticity and genetic stasis may be characteristic of sandy beach species. Soares et al. (1998, 1999) and Laudien et al. (2003) showed no large scale genetic differentiation in the whelk Bullia digitalis (aplanktonic larval phase) and the surf clam Donax serra (planktonic larval phase) in South Africa. Both studies ascribed this to a high degree of plasticity in their behaviour, ecophysiology and morphology, which allowed them to rapidly adapt to environmental changes. The evidence provided above demonstrates that life history traits in sandy beach populations can be highly plastic over latitudinal gradients, with large scale variations in temperature and concurrent environmental variables leading to an adjustment of the phenotype-environment relationship. Plasticity may therefore lead to separate populations displaying differences in behaviour and life history patterns.
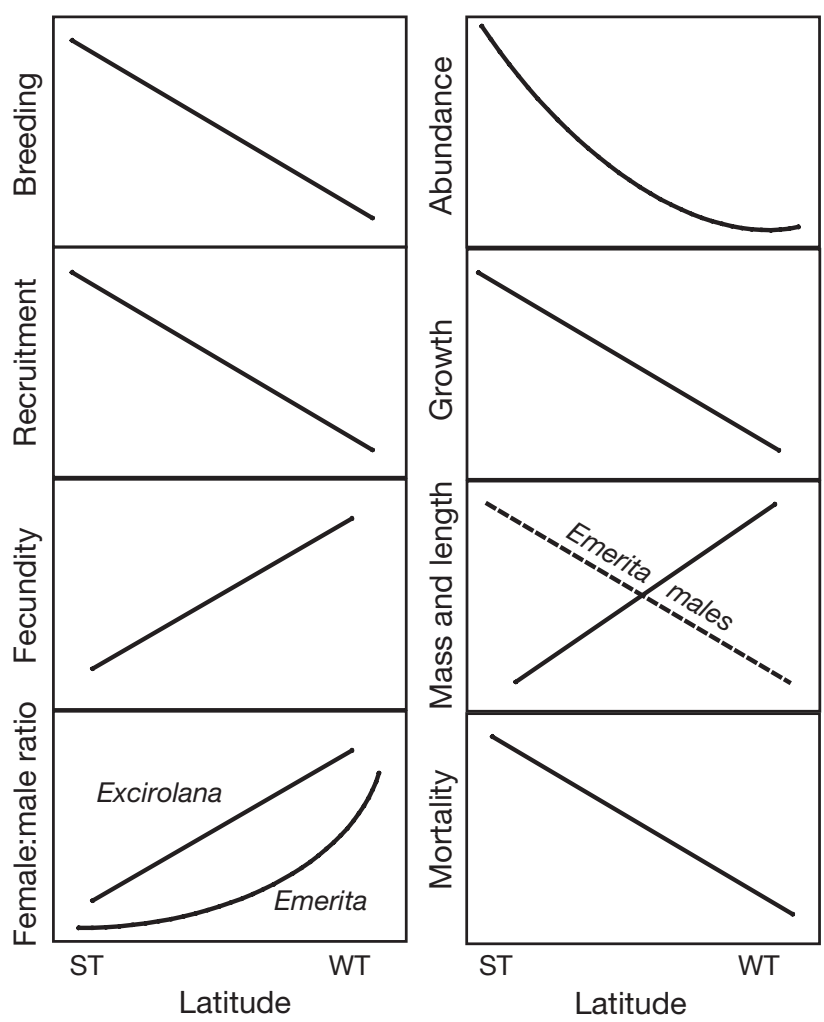

Fig. 5. Emerita brasiliensis and Excirolana braziliensis. Latitudinal patterns in life history traits on South American sandy beaches. Breeding and recruitment refer, respectively, to the frequency of occurrence of ovigerous females and of juveniles throughout a year. In E. brasiliensis, most of these patterns are only valid for females. ST = subtropical, WT = warm temperate
Species ranges, developmental modes and dispersal

Macroscale variations in coastal physiognomy ultimately interact with large scale environmental variables (e.g. temperature) to create asymmetries in the distribution of species. Defeo \& Cardoso (2004) suggested that the mole crab Emerita brasiliensis had a skewed, unimodal distribution pattern within its range, i.e. abundance did not vary smoothly from the central region to range boundaries (see Sagarin \& Gaines 2002). This has been attributed to the disappearance of dissipative sandy beaches, which constitute the suitable habitat for Emerita brasiliensis, in tropical regions, giving way to reflective and pocket beaches, mangrove stands, estuaries and coral reefs (Soares 2003, Defeo \& de Alava 2005).

Episodic environmental events may alter spatial and temporal patterns of abundance, whereas climatic variations over years to decades can result in interannual changes of distribution and abundance (Lima et al. 2000). Distribution limits of beach species can expand and contract over time, displaying considerable fluctuations in abundance coupled with episodic settlement events and/or mass mortalities (Coe 1953). Arntz et al. (1987) showed dramatic fluctuations in the sandy beach bivalves Donax peruvianus and Mesodesma donacium, and the mole crab Emerita analoga in Peru. After the dominant $M$. donacium experienced mass mortalities due to an increase in sea water temperature during an El Niño Southern Oscillation event, $D$. peruvianus increased its representation within the community from 5 to $60-100 \%$ and its density from ca. 20 to 185 ind. $\mathrm{m}^{-2}$, whereas E. analoga increased from $<1$ to $29 \%$, with densities increasing from 0 to 85 ind. $\mathrm{m}^{-2}$. This was accompanied by an expansion of the distributional range to beaches previously unoccupied by these species. On Uruguayan Atlantic beaches, in a guild of suspension feeders of the same genera, Donax hanleyanus and Emerita brasiliensis dramatically increased in density for $10 \mathrm{yr}$ after the dominant Mesodesma mactroides experienced mass mortalities (Defeo 2003). These examples suggest both differential responses to climatic events and also interspecific interactions because of competitive release of resources by dominant community members. In both cases, changes in species composition and abundance occurred after removal of the dominant species, strongly indicating competitive release. Accounting for differences in species life histories and range-limiting factors is therefore necessary in order to better predict macroscale distribution patterns in sandy beach populations.

The mode of species development is crucial to understand the above processes. Sandy beach species have a wide range of development modes, including: 
(1) internal fertilization, the absence of pelagic larval stages, parental care and low fecundity, such as peracarids and whelks, and (2) external fertilization, high fecundity and short-lived (h) or long-lived (from a few weeks to months) planktonic larval stages (e.g. clams: McLachlan et al. 1996b). Species belonging to the latter group are usually structured as metapopulations, with variable degrees of connectivity between local populations through larval dispersal (Defeo 1996b).

Contrasting modes of development, usually found in sandy shores, could influence dispersal patterns. Weinberg \& Starczak (1989) showed an exceptional degree of genetic differentiation between populations of the ovoviviparous isopod Excirolana braziliensis throughout its entire range of distribution in America. This was explained by events of extinction/recolonization, because immigrants of this species with distinct genotypes appeared to not mate randomly and produced hybrids with local members (Lessios \& Weinberg 1994). Although it has been suggested that many local groups of broadcast spawners in open sandy coasts are self-sustaining (Efford 1970), a planktonic larval stage suggests dispersal potential (Sorte et al. 2001) and a variable degree of gene flow among sandy beach populations (Tam et al. 1996).

Population structure and habitat harshness: the source-sink hypothesis

Connectivity patterns between sandy beach populations linked by larval dispersal are an unexplored field of research, and the mechanisms influencing larval distribution are poorly understood (McLachlan et al. 1996b). Hydrographic effects on larval dispersal have yet to be elucidated in terms of planktonic stages and the role of near-shore hydrodynamics in settlement processes. This in turn will determine the spatial scales at which the population is to be considered open, i.e. whether it is more related to the arrival rates of larvae than to post-settlement processes, or whether it could be considered as self-sustaining (Defeo 1996b, Camus \& Lima 2002).

The combination of geographic diversity and local and stable oceanographic structures provides the basis for larval retention areas (Sinclair 1987). Caddy \& Defeo (2003) considered source and sink components in sandy beaches; they assume that 'source populations' are often in areas where there is a high probability of returning water masses or gyres assisting in returning larvae to the local area. If this is true, the age/size structure of the population is probably a good index of the degree of local retention of larvae, and of the probability that their offspring will return to the parental grounds. Thus, source populations should tend to show a good representation of different age classes, as a result of frequent successful annual recruitments, whereas 'sink' populations would be made up of one or few age groups, occurring irregularly in time. In this context, the population structure of Emerita brasiliensis in the upper panel of Fig. 6 could be considered the main source area, because of the presence of all potential year/size classes. Subsequent panels in Fig. 6 represent irregular and sporadic recruitment events of different periodicities. Sink populations have an irregular size structure with sporadic pulses of discrete cohorts, and in some cases biased towards larger size classes because of irregular recruitment pulses causing a discontinuity in the arrival of larvae. Sporadic recruitment pulses and low capacity for self-replenishment in sink populations or at range margins could be caused by several factors, including low fecundity, irregular arrival of larvae due to asymmetric connectivity, or low juvenile survival (Lercari \& Defeo 1999, Sorte et al. 2001). In this case (Fig. 6), source populations with multiple size/age groups coincide with dissipative (Defeo et al. 2002) or undisturbed (Lercari \& Defeo 1999, 2003) systems, so this approach can also be applied to evaluate the rela-

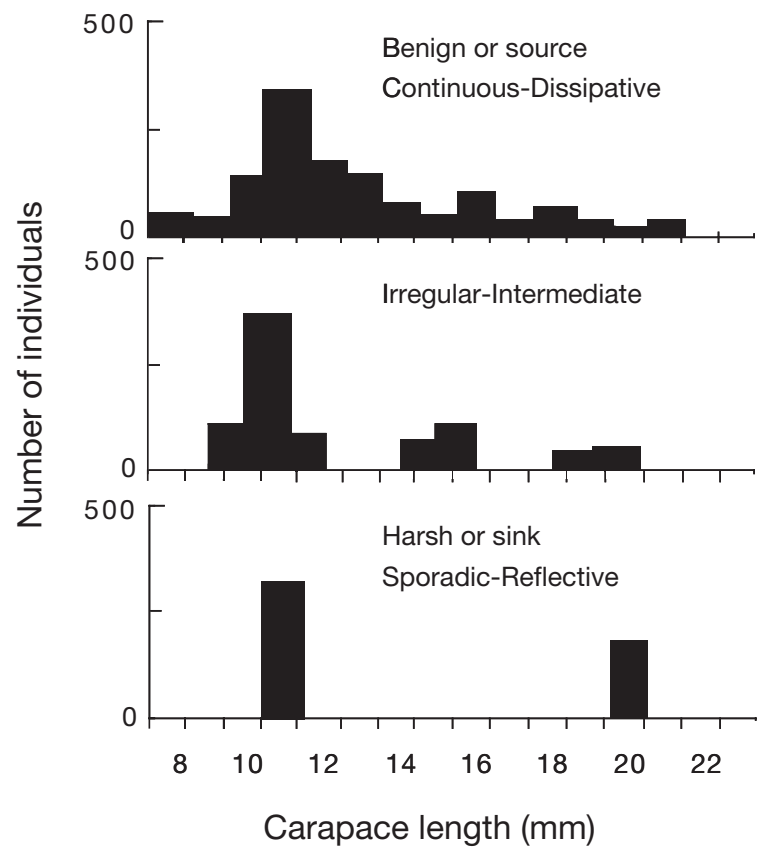

Fig. 6. Emerita brasiliensis. The 'source-sink hypothesis', as illustrated by the length frequency distributions of the mole crab from different beach types. Reproductive females on dissipative beaches seed reflective beaches. Sources (upper panel) and sinks (lower 2 panels) can be identified as a result of larval dispersal, retention in the parental spawning area and differential post-settlement mortality rates. The length/ age population structure in each case depends on the degree of connectivity between populations (from Defeo unpubl.) 
tive importance of morphodynamics or disturbance levels at regional or local spatial scales (Lercari et al. 2002, Defeo \& Lercari 2004).

Information on long term variations in abundance or genetic makeup could help to discern source from sink populations. Large fluctuations in abundance are particularly noticeable in species with planktonic larvae (Coe 1953, 1956, Ansell 1983, McLachlan et al. 1996b), when compared to otherwise similar one-phase species with aplanktonic stages. Moreover, most sandy beach species are short-lived ( 2 to $8 \mathrm{yr}$ ), have rapid growth to maturity, high recruitment fluctuations (McLachlan et al. 1996b), and are represented by age-class dominated populations (Defeo et al. 1992b). Thus, short term variations in abundance could mask the elucidation of sources and sinks.

Population responses to the beach environment

The increase in species diversity, total abundance and biomass from reflective to dissipative beaches is now considered a paradigm at the community level. In contrast, there is a paucity of pertinent hypotheses concerning predictions of population patterns (Defeo et al. 2001); few studies have investigated how species respond to the physical environment demographically, i.e. in terms of abundance, growth, mortality, fecundity and other population features. Tests of the SEH (originally formulated at the community level) and the HHH (emphasis on population level) have found 3 patterns:

(1) The SEH and the HHH have predicted variations in abundance, population dynamics and life history traits of truly intertidal species. Some species are capable of maintaining populations across the whole morphodynamic spectrum, whereas species restricted to dissipative systems are more sensitive to harsh habitats (Defeo et al. 1997, McLachlan \& Dorvlo 2005). Field and laboratory studies have shown increasing abundance (McLachlan 1990, Defeo et al. 1992a, Dugan \& Hubbard 1996, Jaramillo et al. 2000b, Defeo et al. 2002), fecundity, growth, and survival rates (Defeo et al. 2002, Brazeiro 2005) from reflective to dissipative beaches, as well as limited or null capability of burrowing in coarse sands (McLachlan et al. 1995, Nel et al. 1999, 2001, Defeo et al. 2001, de la Huz et al. 2002, Marcomini et al. 2002, Cardoso et al. 2003). Grain size and concurrent changes in swash climate/period may exclude species from coarse-grained beaches (Nel et al. 2001). However, whether exclusion is due to prevention of settlement or to the inability to survive after settlement is uncertain. Higher values for female somatic growth, fecundity, size at maturity and weight at size in dissipative beaches have been related to abundant food availability (Defeo \& Scarabino 1990, Defeo 1993, Dugan et al. 1994). Higher intra-annual variability in abundance and narrower reproductive and recruitment seasons have been observed in reflective beach populations (Defeo et al. 2003). This synchronicity may be an adaptation to reduce the effects of harsh reflective beaches and to increase the probability of copulation with the sparse reproductive females (Defeo et al. 2001). Another explanatory hypothesis proposed here is that 'source' dissipative beaches may seed 'sink' reflective beaches. Thus, high fluctuations in larval supply, depending on connectivity between source and sink populations, may occur in reflective beaches. This new hypothesis needs further testing.

(2) In supralittoral forms, clear population responses to beach type have not been observed in cirolanid isopods (Defeo et al. 1997, 2003, Contreras et al. 2003, Defeo \& Martínez 2003, Caetano et al. 2005) or amphipods (Gómez \& Defeo 1999). They are less influenced by the swash climate and generally have autonomous active movement on upper beach levels (Giménez \& Yannicelli 1997). Defeo \& Gómez (2005) showed that the supralittoral amphipod Atlantorchestoidea brasiliensis exhibited clear population responses to physical variables in a trend opposite to that predicted by the $\mathrm{HHH}$, including an increase in abundance (total, ovigerous females, and juveniles) and individual sizes from dissipative to reflective beaches. Existing hypotheses do not accurately predict population dynamics of supralittoral forms because of a limited appreciation of the role played by life history strategies. The combination of short swashes and steep slopes may, in fact, make microtidal reflective beaches a more stable and safer environment for supralittoral species, because their risk of immersion is substantially lower here than on dissipative beaches. Short (1996) defined modally reflective beaches as the most stable beach type with low backshore mobility. Thus, reflective environments appear to favour supralittoral forms. This has been called the Hypothesis of Habitat Safety for supralittoral forms (Defeo \& Gómez 2005), a refinement of the theory developed to explain morphodynamic effects on sandy beach populations. This separates intertidal and supralittoral forms, taking into account both swash and sand effects and differences in life histories (Defeo et al. 2003, McLachlan \& Dorvlo 2005).

(3) Inadequate sampling of the appropriate temporal and spatial scales has limited testing of the predictions of the SEH and HHH at the population level. In most studies only 2 beaches have been used for comparison, so that trends in population features cannot be rigorously attributed to beach morphodynamics, but only to location. However, extended studies of mole crabs 

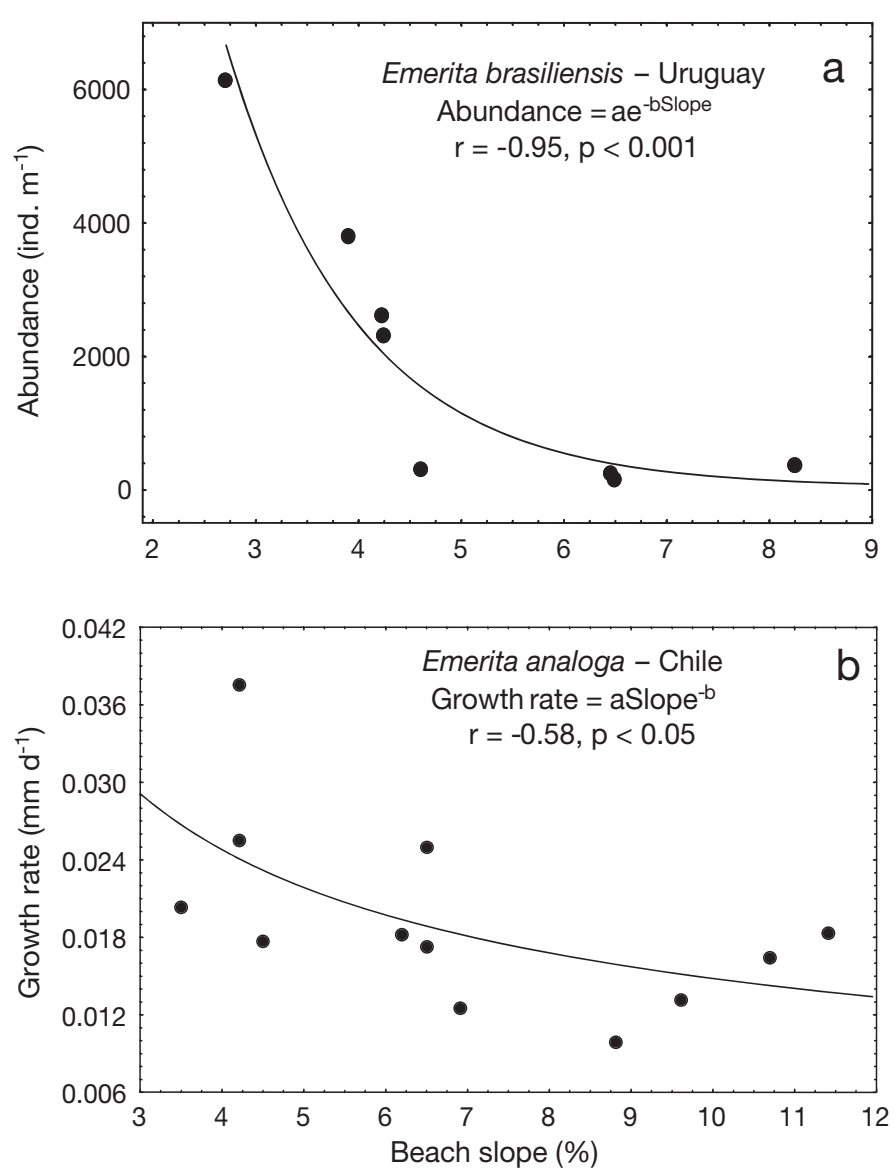

Fig. 7. Emerita brasiliensis and E. analoga. Population features of 2 intertidal core species of the Americas in support of the HHH. (a) Abundance in Uruguay (from Defeo et al. 2002) and (b) individual growth rates in Chile (after Brazeiro 2005) decrease as beach slope becomes steeper, suggesting harsher conditions towards reflective states

Emerita brasiliensis (Defeo et al. 2002, Fig. 7a) and E. analoga (Brazeiro 2005, Fig. 7b) on several beaches covering a wide morphodynamic spectrum support the $\mathrm{HHH}$.

\section{MESOSCALE PATTERNS}

The mesoscale concerns variations within a single beach, i.e. an uninterrupted sandy shore, both in the alongshore and across-shore directions.

\section{Alongshore distribution}

Marked alongshore variation has been documented at the community and population levels. Species richness may increase with beach length (Brazeiro 1999), with short or 'pocket' beaches supporting fewer spe- cies than longer beaches. Species composition and abundance along the shore also decreases with increasing beach slope and grain size, and with decreasing width and relative tide range (Degraer et al. 2003). Lercari et al. (2002) and Lercari \& Defeo (2003) showed that species richness, diversity, evenness, and abundance significantly increased from disturbed sites affected by a freshwater discharge to undisturbed ones.

Sandy beach populations and assemblages may exhibit a well defined alongshore structure with significant across- and alongshore variations (James \& Fairweather 1996). Populations tend to be aggregated in elliptical patches from $\mathrm{m}$ to $\mathrm{km}$, with the major axis parallel to the shore (Defeo et al. 1986, Defeo 1993, Giménez \& Yannicelli 1997), and varying according to the different susceptibility of each species and year group (i.e. recruits vs adults) to environmental factors. Alongshore distribution tends to be unimodal, bellshaped within the beach, with decreasing abundance from the central region to range boundaries (Defeo et al. 1986, Defeo 1993, Defeo \& de Alava 1995, Schoeman 1997, Schoeman \& Richardson 2002). Disturbing agents can shift distributions from bell-shaped to asymmetrical.

Gradients in physical factors invoked to explain alongshore patterns (Bally 1981, McLachlan 1983, Schoeman \& Richardson 2002) have included exposure from sheltered to exposed beach ends, changing sand particle size, swash climate, morphodynamics, salinity, features associated with river mouths, and also passive sorting by the swash, localized food concentrations or behavioural sorting (Wade 1967, Ansell 1983, McLachlan \& Hesp 1984, Defeo et al. 1986, Donn 1987 , Lastra \& McLachlan 1996, McLachlan 1996, Dugan \& McLachlan 1999). Alongshore variation may also result from a combination of biotic (intra and interspecific interactions) and abiotic factors (Wade 1967, Mouëza \& Chessel 1976, Defeo et al. 1986, Defeo 1993, Defeo \& de Alava 1995, Giménez \& Yannicelli 2000, Schoeman \& Richardson 2002). Additional sources of variability include human activity such as artisanal harvesting of target species (Schoeman 1996, Sims-Castley 1997 , Schoeman et al. 2000) and their interspecific competitors for food and space (Defeo \& de Alava 1995), manmade structures, beach nourishment, and bulldozing (Nelson 1989, Lercari \& Defeo 1999, 2003, Peterson et al. 2000, Brown \& McLachlan 2002, Degraer et al. 2003). Dillery \& Knapp (1969) showed active alongshore movements of Emerita of $15 \mathrm{~m} \mathrm{~d}^{-1}$, extrapolated to $5 \mathrm{~km} \mathrm{yr}^{-1}$. However, alongshore movements are less noticeable in bivalves (Dugan \& McLachlan 1999). Alongshore patchiness in supralittoral species has been associated with sediment water content and dune vegetation cover (Giménez \& Yannicelli 2000). 


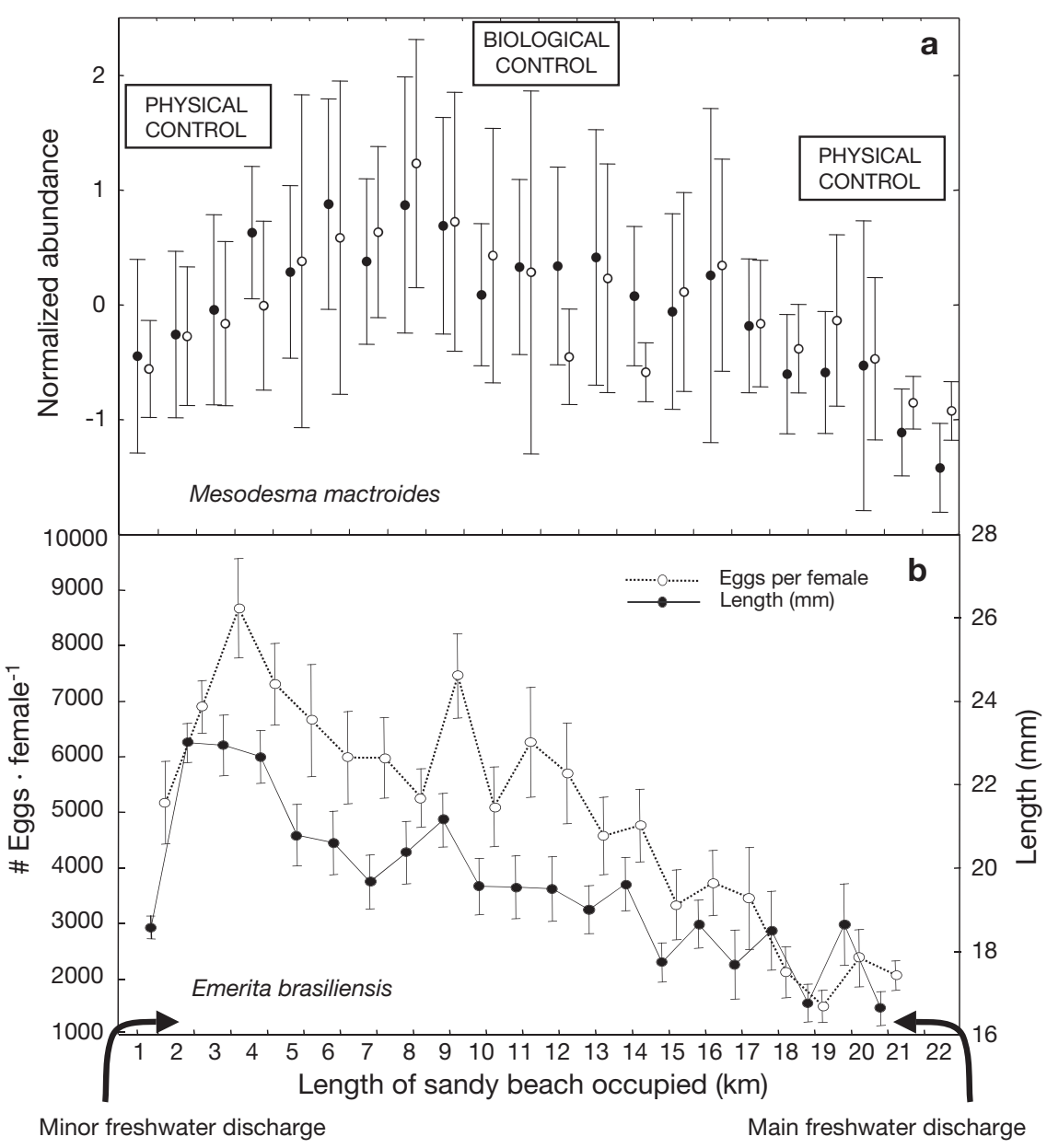

Fig. 8. Mesodesma mactroides and Emerita brasiliensis. (a) Alongshore variability of yellow clam (O) recruits and (•) adults, over favourable and unfavourable loci. Recruits occupied unfavourable habitats only during periods of good recruitment. (b) Effect of habitat unsuitability, measured as the distance from a freshwater discharge, in individual size and fecundity of female mole crabs. Note the local effect produced by a minor freshwater discharge at $\mathrm{Km} 1$ flows), suggesting active dispersal and microhabitat selection (McLachlan \& Hesp 1984, Donn et al. 1986, James 1999).

Habitat suitability may explain variations in the contraction/expansion of the alongshore distribution of a species on a beach. The yellow clam Mesodesma mactroides displayed a sequential pattern of alongshore replenishment along a $22 \mathrm{~km}$ sandy beach, from the central zones of regular recruitment to the marginal portions disturbed by freshwater discharges, and by concurrent changes in other variables (Defeo 1993). When central sites were fully occupied, marginal sites were occupied by later settlers. Alongshore patterns can be explained by the salinity gradient, higher recruit densities in marginal habitats (only in years of good recruitment), and differential growth and mortality between sites (Fig. 8a). In the same beach, mole crabs Emerita brasiliensis displayed reduced individual size and fecundity towards the unsuitable habitat (Fig. 8b), and recruits were found in reduced numbers near the freshwater discharge, a result of high pre-settlement and early post-settlement mortality rates (Lercari \& Defeo 1999).

In summary, the considerable alongshore variation in sandy beach populations takes the form of patchiness on several scales, generated by a combination of abiotic and biotic factors.
On a finer scale, intertidal organisms may experience sorting by alongshore swash circulation resulting in aggregations. Concentration in cusps (spaced undulations of the beach face) has been documented in several sedentary filter feeders (Cubit 1969, Dillery \& Knapp 1969, Perry 1980, McLachlan \& Hesp 1984, Giménez \& Yannicelli 2000). Sorting by cusp swash circulation tended to concentrate less motile forms in the bays, where patches were composed of more small individuals compared to those on promontories (Donn et al. 1986, James 1999). Small organisms living close to the sand surface are subject to greater rates of dislodgement and movement by swash action from promontories to bays than large organisms (James 1999). Alternatively, highly motile species may show uniform distribution throughout cusp systems or even concentrate on promontories (opposite to current
Synthesizing disparate information and following recent theoretical developments (Caddy \& Defeo 2003), we propose a mesoscale hypothesis of environmental favourability for sandy beach populations (Fig. 9). In benign environments, such as dissipative beaches or sites undisturbed by human activity, high abundances promote intraspecific interactions (e.g. density-dependent growth and mortality rates); but in marginal habitats, where harsh and fluctuating conditions lead to lower densities and limited biological interactions, the population is physically controlled and environmentally-dependent growth and mortality prevail over density-dependent mechanisms (Fig. 8a). Peripheral populations within the geographic range of a species (macroscale), or those situated in a marginal portion of a habitat affected by a disturbance source (mesoscale) tend to be physically controlled, whereas 


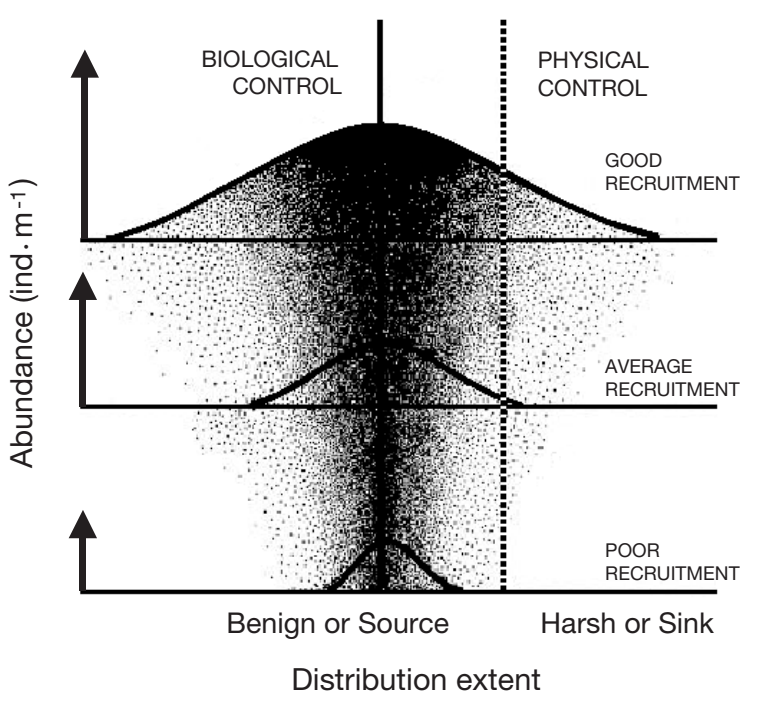

Fig. 9. The Habitat Favourability Hypothesis in sandy beach populations reflecting variations in the contraction or expansion of the distribution of a species on a mesoscale (alongshore or across-shore) or macroscale (range). In benign habitats (dissipative beaches or undisturbed systems) populations are mainly controlled by density-dependent mechanisms, whereas populations in reflective or in grossly disturbed beaches are physically controlled. In a metapopulation context, the solid line shows the expected abundance within source populations (e.g. dissipative beaches), whereas the dashed line shows that sink populations in reflective beaches may be absent in poor recruitment years (after Caddy \& Defeo 2003)

populations situated at the centre of a range or in an undisturbed area are more likely to be influenced by biological factors (cf. Figs 6, 8, 9). This model could also explain the effects of morphodynamics on intertidal species; populations inhabiting reflective beaches should be mostly affected by the harshness of the environment, whereas biological factors may become more important in dissipative beaches (Fig. 4).

\section{Zonation}

\section{Zonation schemes}

Descriptions of zonation of sandy beach macrofauna can be grouped into 4 categories (McLachlan \& Jaramillo 1995): (1) no clear zonation; (2) 2 zones, air breathers above the drift line and water breathers (marine forms) below; (3) 3 zones based originally on Dahl's (1952) analysis of crustaceans (see below); and (4) 4 physical zones based originally on Salvat's (1964) description of sediment moisture content. Following Dahl (1952), 3 zones can be distinguished and defined as: (1) the supralittoral zone of air breathers, present on all shores at and above the drift line and typically inhabited by talitrid amphipods, oniscid isopods or ocypodid crabs; cirolanid isopods of the genus Excirolana may occur around the drift line; (2) the littoral zone, present on all except the harshest reflective beaches, extends from the drift line down the midshore to just above the water table outcrop; true intertidal species, such as cirolanid isopods, haustorid amphipods and spionid polychaetes, are typical; and (3) the sublittoral zone (or fringe) which extends from the surf zone up onto the swash zone a little way above the water table outcrop; a wide variety of species may be encountered, such as donacid bivalves, hippid crabs, mysids, amphipods and polychaetes.

Quantitative analyses give partial support for 3 zones, but the number of recognizable zones depends on beach type, reflective beaches having fewer zones than dissipative beaches (Defeo et al. 1992a, Jaramillo et al. 1993, McLachlan \& Jaramillo 1995, Borzone et al. 1996, Brazeiro \& Defeo 1996, Nel 2001, Veloso et al. 2003, Aerts et al. 2004). In flatter, dissipative beaches, lower zones may frequently be fused and divided, whereas on reflective beaches this occurs in the mid and upper zones. At the extremes of beach morphodynamics, only the supralittoral zone may be found on very harsh reflective beaches and up to 4 zones are recognized on wide dissipative beaches. Macrofaunal zones are dynamic and not sharply defined, corresponding loosely to the moisture gradient across the shore and being defined by the distribution of characteristic species. Aperiodic variation related to short term increases in sea level generated by storm surges and barometric tides will cause the fauna to follow the high water level; alternatively, seasonal variation occurs when species occupy higher levels during spring and summer than in autumn and winter (Defeo et al. 1986, de Alava \& Defeo 1991, Giménez \& Yannicelli 1997, Jaramillo et al. 2000a). As faunal zones are dynamic, temporal studies are needed for a full picture of zonation patterns, requiring intensive sampling to provide unbiased estimates.

\section{Spatial structure and patch dynamics}

At the population level, zonation patterns and patchiness respond to an environment that is spatially and temporally structured by sharp gradients (Bally 1983a,b, McLachlan 1983, Defeo et al. 1986, de Alava \& Defeo 1991, Jaramillo et al. 1994, Schoeman et al. 2003). Aggregations persist in time, but in contrast to sessile species, the across-shore position of patches and their structure varies according to the susceptibility of each species or population component (i.e. recruits and adults) to variations in beach topography, 
morphodynamics, sediment moisture, temperature (Giménez \& Yannicelli 2000, Colombini et al. 2002, Defeo \& Rueda 2002, Cardoso \& Veloso 2003), and food availability, especially in supralittoral species which follow changes in drift line wrack levels (Marsden 1991, Colombini \& Chelazzi 2003).

Population variations in across-shore distribution may arise from physical and biological factors acting on different spatio-temporal scales. Daily variations in zonation are related to changes in tidal levels generated by onshore winds, storm surges, and barometric tides (Brazeiro \& Defeo 1996). Considerable changes have also been observed between spring and neap tides (McLachlan 1983, McLachlan \& Jaramillo 1995). A high orientation capability, particularly in talitrid amphipods, permits zonal recovery in cases of abrupt displacement due to stressful conditions (Scapini et al. 1996). Shifts in zonation between the resting (diurnal) and active (nocturnal) phase have also been shown in talitrid amphipods, with surface activity across-shore varying between adults and juveniles (Scapini et al. 1992, Kennedy et al. 2000, Cardoso 2002, Fallaci et al. 2003). The main microclimatic factor modulating activity in these and other species is sand temperature (Scapini et al. 1997).

Passive transport and sorting by the swash determines differential zonation patterns and patchiness between population components. Smaller individual sizes tend to remain in the swash zone close to the substratum surface and are more dependent on passive transport by waves, whereas large adults regulate their position on the beach by greater mobility and behavioural adaptations, including rapid burrowing (Trueman 1970, McLachlan \& Young 1982, Defeo et al. 1986, Veloso \& Cardoso 1999). Patchy distribution may also be related to made of locomotion, particularly in supralittoral species (Scapini et al. 1995, Brown 1996, Giménez \& Yannicelli 1997). Species-specific behavioural responses to swash climate, manifested in swimming ability, burying, and orientation are also relevant (Yannicelli et al. 2002). These zonation patterns may vary between seasons and do not always coincide with visible boundaries on the beach face, namely the swash zone, the water table outcrop or the drift line (Brazeiro \& Defeo 1996, Colombini et al. 2002).

Segregation by size, documented for amphipods, isopods, mole crabs and clams, suggests a differential capability of each population component to select a desirable microhabitat, as well as a possible evolutionary process to partition space and avoid intraspecific interactions for food or space (Defeo et al. 1986, de Alava 1993, Defeo 1993, Jaramillo et al. 1994, McLachlan \& Jaramillo 1995, Cardoso \& Veloso 2003). Beach levels with optimal environmental conditions (in theory at the centre of the across-shore distributional range) tend to be occupied at high densities by dominant intraspecific competitors for space or food (adults), whereas small individuals (recruits) may be displaced towards suboptimal microhabitats on one or both extremes of the distribution range (de Alava \& Defeo 1991, Kennedy et al. 2000). Between-sex differences in individual size can determine differential zonation patterns, as in Emerita species (Trueman 1970, Veloso \& Cardoso 1999).

Interspecific interactions could account for variations in zonation patterns, thus determining noticeable differences between allopatric and sympatric conditions. Defeo et al. (1997) reported maximum densities of Excirolana armata similar in allopatry and sympatry, but allopatric populations of E. braziliensis were more abundant lower on the shore than at sympatric locations, where distribution was restricted to upper beach levels. McLachlan (1998) and Dugan et al. (2004) provided further evidence of the role of competitive interactions in experiments where changes in burrowing performance of one species were monitored at different densities of other species, even though these effects could be minimal at field densities (McLachlan 1998). Yu et al. (2002) found that feeding habits in 4 sublittoral amphipods could explain variations in zonation; when dietary composition overlapped, spatial segregation reduced competition for food.

Predation can also explain temporal variations in zonation patterns on sandy beaches. Predators perform synchronized migrations that follow daily or seasonal changes in zonation of prey (Ansell et al. 1999). Selective predation by fish and aerial predators, depending on beach levels, could also affect zonation patterns differentially, depending on individual sizes and prey availability (Takahashi et al. 1999, Manning \& Lindquist 2003, Yu et al. 2003). Active microhabitat selection could occur in order to avoid predators or search for food concentrations (Takahashi \& Kawaguchi 1998).

Modelling the spatial structure of sandy beach populations has received increasing attention (Defeo 1993, James \& Fairweather 1996, Giménez \& Yannicelli 2000, Defeo \& Rueda 2002, Schoeman et al. 2003). Recent analysis using geostatistical techniques showed spatially highly autocorrelated and persistent annual zonation patterns of intertidal isopods and clams (Defeo \& Rueda 2002); across-shore-structured processes varied monthly in extent as a function of temporal variations in environmental conditions. The species tended to show bell-shape unimodal distributions, but a bimodal distribution pattern could arise as a result of intraspecific segregation by size during recruitment (de Alava \& Defeo 1991, Defeo \& Rueda 2002). Schoeman et al. (2003) showed that acrossshore patches may develop in response to some process acting at spatial scales close to $3 \mathrm{~m}$. 
Following the Habitat Favourability Hypothesis (Fig. 9), it is hypothesized that the centre of the acrossand alongshore range of a species, under optimal conditions of sand moisture, penetrability, and temperature, may be occupied by larger and dominant intraspecific competitors for space or food, whereas small individuals (recruits) may be displaced towards suboptimal conditions on one or both extremes of the distribution range. The same holds true in the case of interspecific competition.

\section{MICROSCALE PATTERNS}

The microscale or 'quadrat scale' (Defeo 1996a) concerns variations from $\mathrm{mm}$ to $\mathrm{m}$ and covers interactions in high-density patches and encompasses the area of influence of an individual (Hall 1983). Small-scale environmental gradients, together with intra- and interspecific interactions, affect populations at this fine spatial scale (Defeo 1996a, 1998). Small-scale data collected to investigate spatial distribution patterns in sandy beach populations are considered Type 1 (sensu Orensanz et al. 1998), i.e. counts of individuals within quadrats. Type 2 (distances between individuals and their nearest neighbours) and Type 3 (maps of all individuals in a 3-dimensional plot) studies have not been conducted yet, despite their importance for describing spatial patterns.

Microscale spatial patterns in the Manila clam Tapes philippinarum on a sheltered beach (Hall 1983) showed that recruitment depended partly on segregating and congregating forces between larvae attempting settlement and the adult population. The former may result from negative interactions between adults and larvae, which generate a more regular spacing between individuals as a result of competition for space and food or from filtering of larvae by adults during the feeding process. Defeo (1993) documented a more patchy distribution among recruits than among adult clams Mesodesma mactroides, suggesting that individuals tend to space themselves as a function of size. Space limitation increases with density of established adults; high adult density increases the probability that a resident adult population filters out settling larvae, preventing colonization by new recruits (Hall 1983). As in suspension feeders, each animal would establish a territory by its filtering activity, and a 'bottleneck' occurs at high adult den- sity or biomass; for yellow clams this was close to 100 adults $\mathrm{m}^{-2}$ (Defeo 1996b). Filtering out larvae holds bivalve population density below carrying capacity (cf. Peterson 1979).

Scatter diagrams of adult and recruit density per quadrat have been used to assess potential intra- and interspecific interactions (Caddy \& Defeo 2003). At this small scale of spatial resolution, Defeo (1996a) showed that the highest densities of recruits of the yellow clam Mesodesma mactroides were never coincident with the highest densities of older clams. Maximum recruit density per quadrat occurred during a period of active fishing, whereas adult densities were highest immediately after a fishing exclusion experiment. However, at adult densities $>400$ ind. $\mathrm{m}^{-2}$, recruits were almost absent (Fig. 10). The upper boundary of the scatterplot, the Constraint Envelope Pattern (CEP sensu Marquet et al. 1995), represents optimal combinations of adult and recruitment density, whereas values within this 'envelope', well below the upper ceiling, represent suboptimal conditions. Fine scale segregation is consistent with the overcompensatory stock-recruitment relationship in the yellow clam, with inhibition of recruitment at highest adult densities under exclusion of fishing activities (Defeo 1998). Active filtering of larvae during feeding activity was a potential explanatory mechanism.

Dugan et al. (2004) demonstrated negative relationships between the mole crab Emerita analoga and the surf clam Mesodesma donacium at small spatial scales. Spatial overlap in the intertidal distributions of these species varied with abundance in time and space. Highest density zones of each species were distinctly separated at low tide and spatial overlap decreased significantly with increasing density.

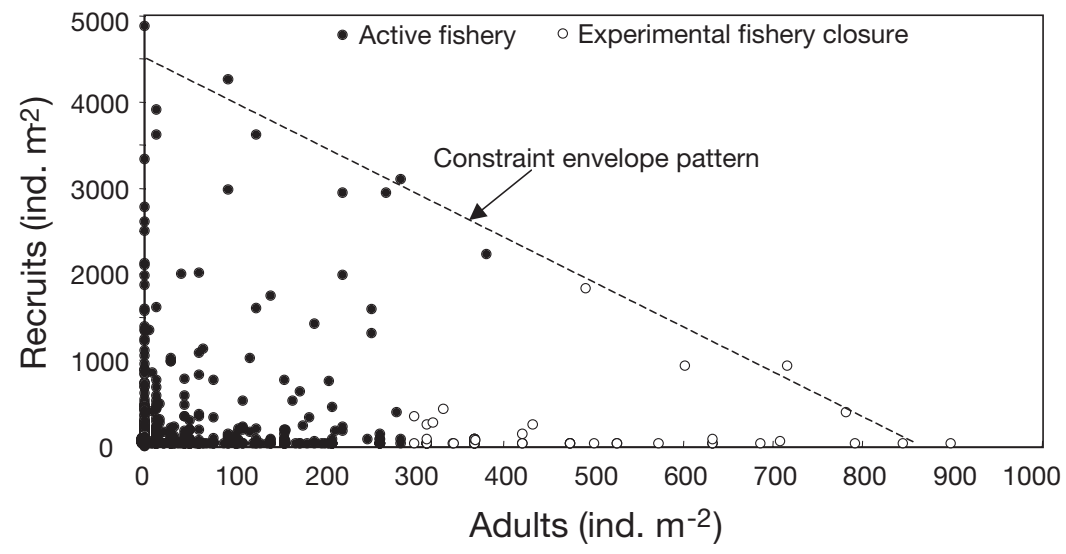

Fig. 10. Mesodesma mactroides. Scatter diagram of yellow clam recruit density plotted against adult density in each quadrat during recruitment periods; recruitment densities peaked under low adult densities and high extraction levels between 1983 and 1987 (•) but were low in 1989-1990 (०) as a result of experimental fishery closure. The broken line defines the constraint envelope (Marquet et al. 1995) between stock and recruitment (data from Defeo 1996a) 


\section{BIOLOGICAL FACTORS}

\section{Competition}

Detection of intra- and interspecific competition in sandy beaches has proven difficult (Branch 1984, Defeo 1996b) because of (1) inherent difficulties in experimentally manipulating the generally small and mobile infauna, (2) the 3-dimensional structure of the habitat which enables horizontal and vertical space partitioning (Peterson 1991), and (3) the absence of information about the scale-dependence of processes structuring populations. However, results from analyses conducted at a variety of spatial scales suggest that intraspecific (Defeo et al. 1992b; Defeo 1996a, Marsden 2002, Schoeman \& Richardson 2002) and interspecific (Defeo \& de Alava 1995, Defeo et al. 1997, McLachlan 1998, Dugan et al. 2004) competition may significantly influence sandy beach fauna. The earliest evidence was provided by Croker \& Hatfield (1980), who found horizontal and vertical space partitioning between 3 sympatric haustoriid amphipods along with differential survival in coexistence experiments in the laboratory (see also Croker 1967). This section reviews findings on the role of competition since Croker \& Hatfield (1980).

Zonation patterns (see above), abundance and survivorship in the sympatric isopods Excirolana armata and $E$. braziliensis are affected by interspecific interactions; a noticeable reduction in body size of both species occurs in sympatric populations (Defeo et al. 1997). E. braziliensis is most abundant in fine sands, and has a greater niche breadth through most of its range than that observed in Uruguay, where it mainly inhabits coarse sands and upper beach levels on reflective beaches, being displaced by E. armata.

Human exclusion experiments are useful tools to detect the role of intra and interspecific competition, because humans can strongly impact the dynamics and demography of sandy beach macrofauna (Defeo \& de Alava 1995, Peterson et al. 2000). A long-term study (1983 to 1990), with a human exclusion experiment based on a fishery closure for 32 mo showed densitydependent growth, mortality, and recruitment of the targeted yellow clam Mesodesma mactroides, suggesting that intraspecific competition affects its dynamics (Castilla \& Defeo 2001). Particularly, there was strong overcompensation in the stock-recruitment relationship, i.e. inhibition of recruitment at high adult densities (Defeo 1993, 1996b). Stochasticity in reproductive rates and asymmetric intercohort interactions (densitydependent recruitment and survival rates) operating together have been identified as key processes generating large variability in yellow clam recruitment (Brazeiro \& Defeo 1999, Lima et al. 2000). Fishing pres- sure on $M$. mactroides explained temporal variations in recruitment in non-targeted species: recruitment density of the sympatric non-targeted bivalve Donax hanleyanus was inversely related to the density of juveniles and adults of the sympatric yellow clam Mesodesma mactroides (de Alava 1993, Defeo 1998), defining an 'interspecific stock-recruitment relationship' (sensu Pauly 1980).

McLachlan (1998) found that intra- and interspecific interactions could occur during burrowing at high densities (400 to 600 ind. $\mathrm{m}^{-2}$ ) of the sympatric Donax serra and Donax sordidus. Asymmetric competition was postulated: the larger $D$. serra, occupying more space at experimental densities, had significant effects on the smaller D. sordidus, but not viceversa. However, the densities required to produce these effects exceeded those normally recorded in the field. In a similar study, Dugan et al. (2004) investigated the hippid crab Emerita analoga and the clam Mesodesma donacium finding burrowing times of large crabs significantly longer in all densities of clams than in controls, and large crabs displacing small clams from the sand while burrowing. Cardoso \& Veloso (2003) showed a negative relationship between densities of Donax hanleyanus and Emerita brasiliensis over time during a 2 yr study, suggesting competition.

We propose that these biotic interactions are particularly meaningful in dissipative beaches with high species richness, high densities, and relatively stable substrate; whereas populations at reflective beaches could be mainly regulated by individual responses to the environment (Defeo et al. 2003, McLachlan \& Dorvlo 2005; see Fig. 4). Since sandy beach populations are highly spatially structured, compensatory and overcompensatory mechanisms are expected to occur at small spatial scales in dissipative beaches with high macrofauna densities.

\section{Predation, mutualism and parasitism}

There is little information on effects of these processes on population dynamics or community structure. Concerning predation, studies on ecosystem energetics have quantified the main trophic structures and energy flows, which vary between beach types: reflective beaches function as interfaces processing organic material inputs from the sea, whereas dissipative beaches may have surf diatom accumulations driving resident food chains in open but functional beach and surf zone ecosystems (Brown \& McLachlan 1990). High primary and secondary production allow higher predation rates at dissipative beaches (Brown \& McLachlan 1990, Colombini \& Chelazzi 1996). Removal of macrofauna production is due to 3 main 
groups of predators: (1) birds, arachnids and insects from land, (2) fishes from the sea, and (3) resident invertebrates, notably crabs. These forms of predation crop populations and result in significant energy flow, but their effects on population dynamics or community structure are still not known.

Positive interspecific interactions within physically stressful habitats have been sparsely documented. Manning \& Lindquist (2003) demonstrated a positive interaction where the clam Donax variabilis facilitated epibiotic occupation by providing a stable substrate for attachment of the hydroid Lovenella gracilis; the hydroid defended the clam against fishes by means of its nematocysts, but facilitated predation by crabs, because projection of the hydroid above the surface of the sand allowed the crabs to more readily detect clams. Depending on relative predation pressure, the occupation of $D$. variabilis by L. gracilis was characterized as beneficial or detrimental to the host.

Parasitism can be a potentially important process influencing demographic patterns and the small-scale spatial distribution of sandy beach macrofauna. Poulin \& Rate (2001) and Poulin \& Latham (2002) demonstrated that parasites affected the burrowing depth of Talorchestia quoyana in New Zealand beaches. Amphipods that harboured larger parasites burrowed deeper than expected based on their body size. Massive natural mortality events decimated yellow clam populations along thousands of $\mathrm{km}$ of sandy beaches in Brazil, Uruguay and in Argentina (Fiori \& Cazzaniga 1999). Parasites could play a role in explaining these mortality events (Cremonte \& Figueras 2004, Fiori et al. 2004), thus providing an alternative explanation to the widely held notion that mass mortalities in beach macrofauna are due to toxins from harmful algal blooms (McLachlan et al. 1996b).

The third dimension, vertical distribution in the sand, is an additional way to partition space in order to ameliorate the strength of biological interactions. This 3-dimensional structure of the sandy beach habitat is a general feature of soft-bottom environments (Peterson \& Andre 1980, Wilson 1991, Peterson 1991), but in the case of sandy beach environments, 3-dimensional studies have not been conducted yet.

\section{CONCLUSIONS}

Sandy beach research has advanced considerably over the past 2 decades. This review, focusing on community and population ecology, has covered a significant body of knowledge and demonstrated an emerging field of research taking form around central paradigms and theories under test. Beach morphodynamic models have become widely accepted and applied at the community level, with consistent largescale patterns of increasingly species rich communities towards dissipative beaches and lower latitudes. Population studies on a variety of scales have examined both the dynamics of commercially exploited populations and the regulation and adaptations of populations in general. We propose here that in benign dissipative beaches or undisturbed sites, intra(density-dependent growth and mortality rates) and interspecific (segregation by species or individual sizes) interactions can be more intense than in reflective beaches or disturbed sites, where the populations are physically controlled (environmentally dependent growth and mortality). We believe the key areas for the future will be investigating the importance of physical and biological factors on finer scales, through population studies and experimental work on ecophysiology and behaviour. Only by deciphering cause and effect relationships at the individual and population levels will we truly begin to understand the processes that underlie the large-scale community patterns that have become clear.

\section{LITERATURE CITED}

Aerts $\mathrm{K}$, Vanagt T, Degraer S, Guartatanga S and 5 others (2004) Macrofaunal community structure and zonation of an Ecuadorian sandy beach (bay of Valdivia). Belg J Zool $134: 17-24$

Alexander RR, Stanton RJ, Dodd JR (1993) Influence of sediment grain size on the burrowing of bivalves: correlation with distribution and stratigraphic persistence of selected neogene clams. Palaios 8:289-303

Ansell AD (1983) The biology of the genus Donax. In: McLachlan A, Erasmus T (eds) Sandy beaches as ecosystems. W Junk, The Hague, p 607-636

Ansell AD, Harvey R, Gunther CP (1999) Recovery from siphon damage in Donax vittatus (Da Costa) (Bivalvia: Donacidae). J Molluscan Stud 65:223-232

Arntz WE, Brey T, Tarazona J, Robles A (1987) Changes in the structure of a shallow sandy-beach community in Peru during an El Niño event. In: Payne AI, Gulland JA, Bink $\mathrm{KH}$ (eds) The Benguela and comparable ecosystems. S Afr J Mar Sci 5:645-658.

Bally R (1981) The ecology of three sandy beaches on the west coast of South Africa. PhD dissertation, University of Cape Town

Bally R (1983a) Factors affecting the distribution of organisms in the intertidal zones of sandy beaches. In: McLachlan A, Erasmus T (eds) Sandy beaches as ecosystems. W. Junk, The Hague, p 391-403

Bally R (1983b) Intertidal zonation on sandy beaches of the west coast of South Africa. Cah Biol Mar 24:85-103

Borzone CA, Souza JRB, Soares AG (1996) Morphodynamic influence on the structure of inter and subtidal macrofaunal communities of subtropical sandy beaches. Rev Chil Hist Nat 69:565-577

Branch GM (1984) Competition between marine organisms: ecological and evolutionary implications. Oceanogr Mar Biol Annu Rev 22:429-593

Brazeiro A (1999) Community patterns in sandy beaches of 
Chile: richness, composition, distribution and abundance of species. Rev Chil Hist Nat 72:93-105

Brazeiro A (2001) The relationship between species richness and morphodynamics in sandy beaches: which are the underlying factors? Mar Ecol Prog Ser 224:35-44

Brazeiro A (2005) Geomorphology induces life history changes in invertebrates of sandy beaches: the case of the mole crab Emerita brasiliensis in Chile. J Mar Biol Assoc UK 85:113-120

Brazeiro A, Defeo O (1996) Macroinfauna zonation in microtidal sandy beaches: is it possible to identify patterns in such variable environments. Estuar Coast Shelf Sci 42: 523-536

Brazeiro A, Defeo O (1999) Effects of harvesting and densitydependence on the demography of sandy beach populations: the yellow clam Mesodesma mactroides of Uruguay. Mar Ecol Prog Ser 182:127-135

Brown AC (1996) Behavioural plasticity as a key factor in the survival and evolution of the macrofauna on exposed sandy beaches. Rev Chil Hist Nat 69:469-474

Brown AC, McLachlan A (1990) Ecology of sandy shores. Elsevier, Amsterdam

Brown AC, McLachlan A (2002) Sandy shore ecosystems and the threats facing them: some predictions for the year 2025. Environ Conserv 29:62-77

Caddy JF, Defeo O (2003) Enhancing or restoring the productivity of natural populations of shellfish and other marine invertebrate resources. FAO Fish Tech Pap 448, FAO, Rome

Caetano CHS, Cardoso RS, Veloso VG, Silva ES (2005) Population biology and secondary production of Excirolana braziliensis (Isopoda: Cirolanidae) in two sandy beaches of Southeastern Brazil. J Coast Res (in press)

Camus PA, Lima M (2002) Populations, metapopulations, and the open-closed dilemma: the conflict between operational and natural population concepts. Oikos 97:433-438

Cardoso RS (2002) Behavioural strategies and surface activity of the sandhopper Pseudorchestoidea brasiliensis (Amphipoda: Talitridae) on a Brazilian beach. Mar Biol 141: 167-173

Cardoso RS, Defeo O (2003) Geographical patterns in reproductive biology of the Pan-American sandy beach isopod Excirolana braziliensis. Mar Biol 143:573-581

Cardoso RS, Defeo O (2004) Biogeographic patterns in life history traits of the Pan-American sandy beach isopod Excirolana braziliensis. Estuar Coast Shelf Sci 61:559-568

Cardoso RS, Veloso VG (2003) Population dynamics and secondary production of the wedge clam Donax hanleyanus (Bivalvia: Donacidae) on a high-energy, subtropical beach of Brazil. Mar Biol 142:153-162

Cardoso RS, Veloso VG, Caetano HS (2003) Life history of Emerita brasiliensis (Decapoda: Hippidae) on two beaches with different morphodynamic characteristics. J Coast Res (Spec Iss 35):392-401

Castilla JC, Defeo O (2001) Latin-American benthic shellfisheries: emphasis on co-management and experimental practices. Rev Fish Biol Fish 11:1-30

Coe WR (1953) Resurgent populations of littoral marine invertebrates and their dependence on ocean currents and tidal currents. Ecology 34:225-229

Coe WR (1956) Fluctuations in populations of littoral marine invertebrates. J Mar Res 15:212-232

Colombini I, Chelazzi L (1996) Environmental factors influencing the surface activity of Eurynebia complanata (Coleoptera, Carabidae). Rev Chil Hist Nat 69:511-537

Colombini I, Chelazzi L (2003) Influence of marine allochthonous input on sandy beach communities. Oceanogr Mar Biol Annu Rev 41:115-159
Colombini I, Aloia A, Bouslama MF, ElGtari M, Fallaci M, Ronconi L, Scapini F, Chelazzi L (2002) Small-scale spatial and seasonal differences in the distribution of beach arthropods on the northwestern Tunisian coast. Are species evenly distributed along the shore? Mar Biol 140: 1001-1012

Contreras H, Jaramillo E, Duarte C, McLachlan A (2003) Population abundances, growth and natural mortality of the crustacean macroinfauna at two sandy beach morphodynamic types in Southern Chile. Rev Chil Hist Nat 76 : 543-561

Cremonte F, Figueras A (2004) Parasites as possible cause of mass mortalities of the critically endangered clam Mesodesma mactroides on the Atlantic coast of Argentina. Bull Eur Assoc Fish Pathol 24:166-171

Croker RA (1967) Niche diversity in five sympatric species of intertidal amphipods (Crustacea: Haustoriidae). Ecol Monogr 49:746 751

Croker RA, Hatfield EB (1980) Space partitioning and interactions in an intertidal sand burrowing amphipod guild. Mar Biol 61:79-88

Cubit J (1969) The behavior and physical factors causing migration and aggregation in the sand crab Emerita analoga (Stimpson). Ecology 50:118-123

Dahl E (1952) Some aspects of the ecology and zonation of the fauna on sandy beaches. Oikos 4:1-27

de Alava A (1993) Interdependencias ecológicas entre dos bivalvos simpátricos en una playa arenosa de la costa atlántica uruguaya. MSc dissertation, CINVESTAV-IPN, Merida

de Alava A, Defeo O (1991) Distributional pattern and population dynamics of Excirolana armata (Isopoda: Cirolanidae) in an Uruguayan sandy beach. Estuar Coast Shelf Sci 33:433-444

de la Huz R, Lastra M, López J (2002) The influence of sediment grain size on burrowing, growth and metabolism of Donax trunculus L. (Bivalvia: Donacidae). J Sea Res 47: 85-95

Defeo O (1993) The effect of spatial scales in population dynamics and modelling of sedentary fisheries: the yellow clam Mesodesma mactroides of an Uruguayan exposed sandy beach. PhD dissertation, CINVESTAVIPN, Merida

Defeo O (1996a) Experimental management of an exploited sandy beach bivalve population. Rev Chil Hist Nat 69: 605-614

Defeo O (1996b) Recruitment variability in sandy beach macroinfauna: much to learn yet. Rev Chil Hist Nat 69: $615-630$

Defeo O (1998) Testing hypotheses on recruitment, growth and mortality in exploited bivalves: an experimental perspective. Can Spec Publ Fish Aquat Sci 125:257-264

Defeo O (2003) Marine invertebrate fisheries in sandy beaches: an overview. J Coast Res (Spec Iss 35):56-65

Defeo O, Cardoso R (2002) Macroecology of population dynamics and life history traits of the mole crab Emerita brasiliensis in Atlantic sandy beaches of South America. Mar Ecol Prog Ser 239:169-179

Defeo O, Cardoso R (2004) Latitudinal patterns in abundance and life-history traits of the mole crab Emerita brasiliensis on South American sandy beaches. Divers Distrib 10: 89-98

Defeo O, de Alava A (1995) Effects of human activities on long-term trends in sandy beach populations: the wedge clam Donax hanleyanus in Uruguay. Mar Ecol Prog Ser 123:73-82

Defeo O, de Alava A (2005) South America, coastal ecology: 
sandy beach ecosystems in South America. In: Schwartz ML (ed) Encyclopedia of coastal science. Springer, Dordrecht, p 888-892

Defeo O, Gómez J (2005) Morphodynamics and habitat safety in sandy beaches: life history adaptations in a supralittoral amphipod. Mar Ecol Prog Ser 293:143-153

Defeo O, Lercari D (2004) Testing taxonomic resolution levels for ecological monitoring in sandy beach macrobenthic communities. Aquat Conserv 14:65-74

Defeo O, Martínez G (2003) The habitat harshness hypothesis revisited: life history of the isopod Excirolana braziliensis in sandy beaches with contrasting morphodynamics. J Mar Biol Assoc UK 83:331-340

Defeo O, Rueda M (2002) Spatial structure, sampling design and abundance estimates in sandy beach macroinfauna: some warnings and new perspectives. Mar Biol 140: 1215-1225

Defeo O, Scarabino V (1990) Ecological significance of a possible deposit-feeding strategy in Mesodesma mactroides (Deshayes, 1854) (Mollusca: Pelecypoda). Atlantica 12: $55-65$

Defeo O, Layerle C, Masello A (1986) Spatial and temporal structure of the yellow clam Mesodesma mactroides (Deshayes, 1854) in Uruguay. Medio Ambiente (Chile) 8: 48-57

Defeo O, Jaramillo E, Lyonnet A (1992a) Community structure and intertidal zonation of the macroinfauna in the Atlantic coast of Uruguay. J Coast Res 8:830-839

Defeo O, Ortiz E, Castilla JC (1992b) Growth, mortality and recruitment of the yellow clam Mesodesma mactroides on Uruguayan beaches. Mar Biol 114:429 437

Defeo O, Brazeiro A, de Alava A, Riestra G (1997) Is sandy beach macroinfauna only physically controlled? Role of substrate and competition in isopods. Estuar Coast Shelf Sci 45:453-462

Defeo O, Gómez J, Lercari D (2001) Testing the swash exclusion hypothesis in sandy beach populations: the mole crab Emerita brasiliensis in Uruguay. Mar Ecol Prog Ser 212: $159-170$

Defeo O, Lercari D, Celentano E, Lozoya JP, Martínez G (2002) Pautas biológico-pesqueras para el desarrollo de una pesquería artesanal del crustáceo Emerita brasiliensis en la costa atlántica uruguaya. Tech Rep CSIC, Universidad de la República, Montevideo

Defeo O, Lercari D, Gómez J (2003) The role of morphodynamics in structuring sandy beach populations and communities: what should be expected? J Coast Res (Spec Iss) 35:352-362

Degraer S, Volckaert A, Vincx M (2003) Macrobenthic zonation patterns along a morphodynamical continuum of macrotidal, low bar/rip and ultradissipative sandy beaches. Estuar Coast Shelf Sci 56:459-468

Dexter DM (1977) Natural history of the Pan-American sand beach isopod Excirolana braziliensis (Crustacea: Malacostraca). J Zool Lond 183:103-109

Dexter DM (1992) Sandy beach community structure: the role of exposure and latitude. J Biogeogr 19:59-66

Dillery DC, Knapp LV (1969) Longshore movements of the sand crab Emerita analoga (Decapoda: Hippidae). Crustaceana 18:233-240

Donn JE (1987) Longshore distribution of Donax serra in two log spiral bays in the Eastern Cape, South Africa. Mar Ecol Prog Ser 35:217-222

Donn JE, Clark DJ, McLachlan A, du Toit P (1986) Distribution and abundance of Donax serra Röding (Bivalvia: Donacidae) as related to beach morphology. I. Semilunar migrations. J Exp Mar Biol Ecol 102:121-131
Dugan JE, Hubbard DM (1996) Local variation in populations of the sand crab Emerita analoga on sandy beaches in southern California. Rev Chil Hist Nat 69:579-588

Dugan JE, McLachlan A (1999) An assessment of longshore movement in Donax serra Röding (Bivalvia: Donacidae) on an exposed sandy beach. J Exp Mar Biol Ecol 234:111-124

Dugan JE, Wenner AM, Hubbard DM (1991) Geographic variation in the reproductive biology of the sand crab, Emerita analoga (Stimpson) on the California coast. J Exp Mar Biol Ecol 150:63-81

Dugan JE, Hubbard DM, Wenner AM (1994) Geographic variation in life history of the sand crab, Emerita analoga (Stimpson) on the California coast: relationships to environmental variables. J Exp Mar Biol Ecol 181:255-278

Dugan JE, Hubbard DM, Lastra M (2000) Burrowing abilities and swash behaviour of three crabs, Emerita analoga Stimpson, Blepharipoda occidentalis Randall, and Lepidopa californica Efford (Anomura, Hippoidea), of exposed sandy beaches. J Exp Mar Biol Ecol 255:229-245

Dugan JE, Jaramillo E, Hubbard DM, Contreras H, Duarte C (2004) Competitive interactions in macroinfaunal animals of exposed sandy beaches. Oecologia 139:630-640

Efford IE (1970) Recruitment to sedentary marine populations as exemplified by the sand crab, Emerita analoga (Decapoda, Hippidae). Crustaceana 18:293-308

Fallaci M, Colombini I, Lagar M, Scapini F, Chelazzi L (2003) Distribution patterns of different age classes and sexes in a Tyrrhenian population of Talitrus saltator (Montagu). Mar Biol 142:101-110

Fiori S, Cazzaniga N (1999) Mass mortality of the yellow clam, Mesodesma mactroides (Bivalvia, Mesodesmatidae) in Monte Hermoso beach, Argentina. Biol Conserv 89: 305-309

Fiori S, Defeo O (2005) Biogeographic patterns in life history traits of the yellow clam Mesodesma mactroides in sandy beaches of South America. J Coast Res (in press)

Fiori S, Vidal-Martínez V, Simá-Álvarez R, Rodríguez-Canul R, Aguirre-Macedo ML, Defeo O (2004) Field and laboratory observations of the mass mortality of the yellow clam Mesodesma mactroides in South America: the case of Isla del Jabalí, Argentina. J Shellfish Res 23:451-455

Fish S (1970) The biology of Eurydice pulchra (Crustacea: Isopoda). J Mar Biol Assoc UK 50:753-768

Giménez L, Yannicelli B (1997) Variability of zonation patterns in temperate microtidal Uruguayan beaches with different morphodynamic types. Mar Ecol Prog Ser 160: 197-207

Giménez L, Yannicelli B (2000) Longshore patterns of distribution of macroinfauna on a Uruguayan sandy beach: an analysis at different spatial scales and of their potential causes. Mar Ecol Prog Ser 199:111-125

Glynn PW, Dexter DM, Bowman TE (1975) Excirolana braziliensis, a Pan-American sand beach isopod: taxonomic status, zonation and distribution. J Zool Lond 175: $509-522$

Gómez J, Defeo O (1999) Life history of the sandhopper Pseudorchestoidea brasiliensis (Amphipoda) in sandy beaches with contrasting morphodynamics. Mar Ecol Prog Ser 182:209-220

Hacking N (1997) Sandy beach macrofauna of eastern Australia: a geographical comparison. PhD thesis, University of New England, Armidale

Hall MA (1983) A spatial approach to the population dynamics of the Manila clam (Tapes philippinarum). $\mathrm{PhD}$ thesis, University of Washington, Seattle

James RJ (1999) Cusps and pipis on a sandy ocean beach in New South Wales. Aust J Ecol 24:587-592 
James RJ, Fairweather PG (1996) Spatial variation of intertidal macrofauna on a sandy ocean beach in Australia. Estuar Coast Shelf Sci 43:81-107

Jaramillo E, McLachlan A, Coetzee P (1993) Intertidal zonation patterns of macroinfauna over a range of exposed sandy beaches in South-Central Chile. Mar Ecol Prog Ser 101:105-118

Jaramillo E, Pino M, Filún L, González M (1994) Longshore distribution of Mesodesma donacium (Bivalvia: Mesodesmatidae) on a sandy beach of the south of Chile. Veliger 37:192-200

Jaramillo E, McLachlan A, Dugan J (1995) Total sample area and estimates of species richness in exposed sandy beaches. Mar Ecol Prog Ser 119:311-314

Jaramillo E, Duarte C, Contreras H (2000a) Sandy beach macroinfauna from the coast of Ancud, Isla de Chiloe, Southern Chile. Rev Chil Hist Nat 73:771-786

Jaramillo E, Dugan J, Contreras H (2000b) Abundance, population structure, tidal movement and burrowing rate of Emerita analoga (Stimpson 1857) (Anomura, Hippidae) at a dissipative and a reflective sandy beach in south central Chile. PSZN I Mar Ecol 21:113-127

Jaramillo E, Contreras H, Duarte C, Quijón P (2001) Relationships between community structure of the intertidal macroinfauna and sandy beach characteristics along the Chilean coast. PSZN I Mar Ecol 22:323-342

Jones DA (1970) Population densities and breeding in Eurydice pulchra and Eurydice affinis in Britain. J Mar Biol Assoc UK 50:635-655

Kennedy F, Naylor E, Jaramillo E (2000) Ontogenetic differences in the circadian locomotor activity rhythm of the talitrid amphipod crustacean Orchestoidea tuberculata. Mar Biol 137:511-517

Klapow LA (1970) Ovoviviparity in the genus Excirolana (Crustacea: Isopoda). J Zool Lond 162:359-369

Lastra M, McLachlan A (1996) Spatial and temporal variations in recruiment of Donax serra Röding (Bivalvia: Donacidae) on an exposed sandy beach of South Africa. Rev Chil Hist Nat 69:631-639

Laudien J, Flint NS, van der Bank FH, Brey T (2003) Genetic and morphological variation in four populations of the surf clam Donax serra (Roding) from southern African sandy beaches. Biochem Syst Ecol 31:751-772

Lercari D, Defeo O (1999) Effects of freshwater discharge in sandy beach populations: the mole crab Emerita brasiliensis in Uruguay. Estuar Coast Shelf Sci 49:457-468

Lercari D, Defeo O (2003) Variation of a sandy beach macrobenthic community along a human-induced environmental gradient. Estuar Coast Shelf Sci 58:17-24

Lercari D, Defeo O, Celentano E (2002) Consequences of a freshwater canal discharge on the benthic community and its habitat on an exposed sandy beach. Mar Pollut Bull 44: 1397-1404

Lessios HA, Weinberg JR (1994) Genetic and morphological divergence among morphotypes of the isopod Excirolana on the two sites of the Isthmus of Panama. Evolution 48: $530-548$

Lessios HA, Weinberg JR, Starczack VR (1994) Temporal variation in populations of the marine isopod Excirolana: how stable are gene frequencies and morphology? Evolution 48:549-563

Lima M, Brazeiro A, Defeo O (2000) Population dynamics of the yellow clam Mesodesma mactroides: recruitment variability, density-dependence and stochastic processes. Mar Ecol Prog Ser 207:97-108

Manning ML, Lindquist N (2003) Helpful habitant or pernicious passenger: interactions between an infaunal bivalve, an epifaunal hydroid and three potential predators Oecologia 134:415-422

Marcomini SC, Penchaszadeh P, Lopez RA, Luzzatto D (2002) Beach morphodynamics and clam (Donax hanleyanus) densities in Buenos Aires, Argentina. J Coast Res 18: 601-611

Marquet PA, Navarrete SA, Castilla JC (1995) Body size, population density, and the energetic equivalence rule. J Anim Ecol 66:325-332

Marsden ID (1991) Kelp-sandhopper interactions on a sand beach in New Zealand. I. Drift composition and distribution. J Exp Mar Biol Ecol 152:61-74

Marsden ID (2002) Recruitment in the swash zone-temporal variations in juvenile recruitment of an exposed sand beach surf clam. Hydrobiologia 477:47-57

McArdle S, McLachlan A (1991) Dynamics of the swash zone and effluent line on sandy beaches. Mar Ecol Prog Ser 76: 91-99

McArdle S, McLachlan A (1992) Sandy beach ecology: swash features relevant to the macrofauna. J Coast Res 8 398-407

McLachlan A (1980) Exposed sandy beaches as semi-closed ecosystems. Mar Environ Res 4:5963

McLachlan A (1983) Sandy beach ecology: a review. In: McLachlan A, Erasmus T (eds) Sandy beaches as ecosytems. W Junk, The Hague, p 321-380

McLachlan A (1990) Dissipative beaches and macrofauna communities on exposed intertidal sands. J Coast Res 6: $57-71$

McLachlan A (1996) Physical factors in benthic ecology: effects of changing sand particle size on beach fauna. Mar Ecol Prog Ser 131:205-217

McLachlan A (1998) Interactions between two species of Donax on a high energy beach: an experimental approach. J Molluscan Stud 64:492-495

McLachlan A (2001) Coastal beach ecosystems. In: Lewin R (ed) Encyclopedia of Biodiversity. Academic Press, New York, p 741-751

McLachlan A, Dorvlo A (2005) Global patterns in sandy beach macrobenthic communities. J Coast Res 21:674-687

McLachlan A, Erasmus T (1983) Sandy beaches as ecosystems. W Junk, The Hague

McLachlan A, Hesp D (1984) Faunal response to morphology and water circulation of a sandy beach with cusp. Mar Ecol Prog Ser 19:133-144

McLachlan A, Jaramillo E (1995) Zonation on sandy beaches. Oceanogr Mar Biol Annu Rev 33:305-335

McLachlan A, Turner I (1994) The interstitial environment of sandy beaches. PSZN I Mar Ecol 15:177-211

McLachlan A, Young N (1982) Effects of low temperature on the burrowing rates of four sandy beach molluscs. J Exp Mar Biol Ecol 65:275-284

McLachlan A, Woodridge T, Dye AH (1981) The ecology of sandy beaches in southern Africa. S Afr J Zool 16:219-231

McLachlan A, Jaramillo E, Donn TE, Wessels F (1993) Sand beach macrofauna communities: a geographical comparison. J Coast Res 15:27-38

McLachlan A, Jaramillo E, Defeo O, Dugan J, de Ruyck A, Coetzee P (1995) Adaptations of bivalves to different beach types. J Exp Mar Biol Ecol 187:147-160

McLachlan A, De Ruyck AMC, Hacking N (1996a) Community structure on sandy beaches: patterns of richness and zonation in relation to tide range and latitude. Rev Chil Hist Nat 69:451-467

McLachlan A, Dugan JE, Defeo O, Ansell AD, Hubbard DM, Jaramillo E, Penchaszadeh P (1996b) Beach clam fisheries. Oceanogr Mar Biol Annu Rev 34:163-232 
McLachlan A, Fisher M, Al-Habsi HN, Al-Shukairi S, AlHabsi AM (1998) Ecology of sandy beaches in Oman. J Coast Conserv 4:181-190

Mouëza M, Chessel D (1976) Contribution à l'étude de la biologie de Donax trunculus L. (Mollusque: Lamellibranche) dans l'Algerios: analyse statistique de la dispersion le long d'une plage en Baie de Bou Ismaïl. J Exp Mar Biol Ecol 21:211-221

Nel P (1995) The effect of sand particle size on sandy beach macrofauna. MSc thesis, University of Port Elizabeth

Nel P (2001) Physical and biological factors structuring sandy beach macrofauna communities. PhD dissertation, University of Cape Town

Nel R, McLachlan A, Winter D (1999) The effect of sand particle size on the burrowing ability of the beach mysid Gastrosaccus psammodytes Tattersall. Estuar Coast Shelf Sci 48:599-604

Nel R, McLachlan A, Winter DPE (2001) The effect of grain size on the burrowing of two Donax species. J Exp Mar Biol Ecol 265:219-238

Nelson WG (1989) An overview of the effects of beach nourishment on the sand beach fauna. In: Tait LS (ed) Beach preservation technology '88: problems and advances in beach nourishment. Florida Shore and Beach Preservation Association, Tallahassee, FL, p 295-310

Noy-Meir I (1979) Structure and function of desert ecosystems. Israel $\mathrm{J}$ Bot 28:1-19

Orensanz JM, Parma AM, Hall MA (1998) The analysis of concentration and crowding in shellfish research. Can Spec Publ Fish Aquat Sci 125:143-157

Pauly D (1980) A new methodology for rapidly acquiring basic information on tropical fish stocks: growth, mortality and stock-recruitment relationship. In: Saila SB, Roedel PM (eds) Stock assessment for tropical small-scale fisheries. Proc Int Workshop Univ Rhode Island, Narragansett, p $154-172$

Perry DM (1980) Factors influencing aggregation patterns in the sand crab Emerita analoga (Crustacea: Hippidae). Oecologia 45:379-384

Peterson CH (1979) Predation, competitive exclusion, and diversity in the soft-sediment benthic communities of estuaries and lagoons. In: Livingston RJ (ed) Ecological processes in coastal and marine systems. Plenum Press, New York, p 233-264

Peterson $\mathrm{CH}$ (1991) Intertidal zonation of marine invertebrates in sand and mud. Am Sci 79:236-249

Peterson CH, Andre SV (1980) An experimental analysis of interspecific competition among marine filter feeders in a soft-sediment environment. Ecology 61:129-139

Peterson CH, Hickerson DHM, Grissom-Johnson G (2000) Short-term consequences of nourishment and bulldozing on the dominant large invertebrates of a sandy beach. J Coast Res 16:368-378

Poulin R, Latham DM (2002) Parasitism and the burrowing depth of the beach hopper Talorchestia quoyana (Amphipoda: Talitridae). Anim Behav (Part B) 63:269-275

Poulin R, Rate SR (2001) Small-scale spatial heterogeneity in infection levels by symbionts of the amphipod Talorchestia quoyana (Talitridae). Mar Ecol Prog Ser 212:211-216

Riccardi A, Bourget E (1999) Global patterns of macroinvertebrate biomass in marine intertidal communities. Mar Ecol Prog Ser 185:21-35

Rodil IF, Lastra M (2004) Environmental factors affecting benthic macrofauna along a gradient of intermediate sandy beaches in northern Spain. Estuar Coast Shelf Sci 61: $37-44$

Sagarin RD, Gaines SD (2002) The 'abundant centre' distribu- tion: to what extent is it a biogeographical rule? Ecol Lett $5: 137-147$

Salvat B (1964) Les conditiones hydrodynamiques interstitielles des sediments meubles intertidaux et la repartition verticale de la faune endogee. CR Acad Sci Paris 259: 1576-1579

Scapini F, Chelazzi L, Colombini I, Fallaci M (1992) Surfaceactivity, zonation and migrations of Talitrus saltator on a Mediterranean beach. Mar Biol 112:573-581

Scapini F, Buiatti M, De Matthaeis E, Mattoccia M (1995) Orientation behaviour and heterozygosity of sandhopper populations in relation to stability of beach environments. J Evol Biol 8:43-52

Scapini F, Fallaci M, Mezzetti MC (1996) Orientation and migration in Talitrus saltator. Rev Chil Hist Nat 69: 553-563

Scapini F, Audoglio M, Chelazzi L, Colombini I, Fallaci M (1997) Astronomical, landscape and climatic factors influencing oriented movements of Talitrus saltator in nature. Mar Biol 128:63-72

Schoeman D (1996) An assessment of a recreational beach clam fishery: current fishing pressure and opinions regarding the initiation of a commercial clam harvest. S Afr J Wildl Res 26:160-170

Schoeman DS (1997) Spatial and temporal dynamics of Donax serra in St. Francis Bay: implications for a potential fishery. $\mathrm{PhD}$ thesis, University of Port Elizabeth

Schoeman DS, Richardson AJ (2002) Investigating biotic and abiotic factors affecting recruitment of an intertidal clam on an exposed sandy beach using a generalized additive model. J Exp Mar Biol Ecol 276:67-81

Schoeman DS, McLachlan A, Dugan JE (2000) Lessons from a disturbance experiment in the intertidal zone of an exposed sandy beach. Estuar Coast Shelf Sci 50:869-884

Schoeman DS, Wheeler M, Wait M (2003) The relative accuracy of standard estimators for macrofaunal abundance and species richness derived from selected intertidal transect designs used to sample exposed sandy beaches. Estuar Coast Shelf Sci 58 S: 5-16

Short AD (1996) The role of wave height, slope, tide range and embaymentisation in beach classification: a review. Rev Chil Hist Nat 69:589-604

Sims-Castley R (1997) Resource economics of Donax serra in the Eastern Cape: evaluation of a small scale clam fishery. MSc thesis, University of Port Elizabeth

Sinclair M (1987) Marine populations. Washington Sea Grant Program. University of Washington Press, Seattle

Soares AG (2003) Sandy beach morphodynamics and macrobenthic communities in temperate, subtropical and tropical regions - a macroecological approach. PhD thesis, University of Port Elizabeth

Soares AG, Callahan RK, De Ruyck AMC (1998) Microevolution and phenotypic plasticity in Donax serra Röding (Bivalvia: Donacidae) on high energy sandy beaches. J Molluscan Stud 64:407-421

Soares AG, Scapini F, Brown AC, McLachlan A (1999) Phenotypic plasticity, genetic similarity and evolutionary inertia in changing environments. J Molluscan Stud 65: 136-139

Sorte CJ, Peterson WT, Morgan CA, Emmett RL (2001) Larval dynamics of the sand crab, Emerita analoga, off the central Oregon coast during a strong El Niño period. J Plankton Res 23:939-944

Takahashi K, Kawaguchi K (1998) Diet and feeding rhythm of the sand-burrowing mysids Archaeomysis kokuboi and A. japonica in Otsuchi Bay, northeastern Japan. Mar Ecol Prog Ser 162:191-199 
Takahashi K, Hirose T, Kawaguchi K (1999) The importance of intertidal sand-burrowing peracarid crustaceans as prey for fish in the surf-zone of a sandy beach in Otsuchi Bay, northeastern Japan. Fish Sci 65:856-864

Tam YK, Kornfield I, Ojeda FP (1996) Divergence and zoogeography of mole crabs, Emerita spp. (Decapoda: Hippidae) in the Americas. Mar Biol 125:489-497

Trueman ER (1970) The mechanism of burrowing of the mole crab, Emerita. J Exp Biol 53:701-710

Veloso VG, Cardoso RS (1999) Population biology of the mole crab Emerita brasiliensis (Decapoda: Hippidae) at Urca beach, Brazil. J Crustac Biol 19:147-153

Veloso VG, Cardoso RS (2001) The effect of morphodynamics on the spatial and temporal variation of the macrofauna of three sandy beaches on the Rio de Janeiro state, Brazil. J Mar Biol Assoc UK 81:369-375

Veloso VG, Caetano CHS, Cardoso RS (2003) Composition, structure and zonation of intertidal macrofauna in relation to physical factors in microtidal sandy beaches in Rio de Janeiro State, Brazil. Sci Mar 67:393-402

Wade BA (1967) Studies on the biology of the West Indian beach clam Donax denticulatus Linne: I. Ecology. Bull Mar Sci 17:149-174

Weinberg JR, Starczak VR (1988) Morphological differences and low dispersal between local populations of the tropi-

Editorial responsibility: Otto Kinne (Editor-in-Chief), Oldendorf/Luhe, Germany cal beach isopod, Excirolana braziliensis. Bull Mar Sci 42:296-309

Weinberg JR, Starczak VR (1989) Morphological divergence of the Eastern Pacific and Caribbean isopods: effects of a land barrier and the Panama Canal. Mar Biol 103: 143-152

Wenner AM, Ricard Y, Dugan J (1987) Hippid crab population structure and food availability on pacific shorelines. Bull Mar Sci 4:221-233

Willig MR, Kaufman DM, Stevens RD (2003) Latitudinal gradients of biodiversity: pattern, process, scale and synthesis. Annu Rev Ecol Evol Syst 34:273-309

Wilson WH (1991) Competition and predation in marine softsediment communities. Annu Rev Ecol Syst 21:221-241

Yannicelli B, Palacios R, Giménez L (2002) Swimming ability and burrowing time of two cirolanid isopods from different levels of exposed sandy beaches. J Exp Mar Biol Ecol 273: 73-88

Yu OH, Soh HY, Suh HL (2002) Seasonal zonation patterns of benthic amphipods in a sandy shore surf zone of Korea. J Crustac Biol 22:459-466

$\mathrm{Yu} \mathrm{OH}$, Suh HL, Shirayama Y (2003) Feeding ecology of three amphipod species Synchelidium lenorostralum, S. trioostegitum and Gitanopsis japonica in the surf zone of a sandy shore. Mar Ecol Prog Ser 258:189-199

Submitted: September 3, 2004; Accepted: May 16, 2005

Proofs received from author(s): June 17, 2005 